\title{
Urban planning in socialist Croatia
}

\section{Urbano planiranje u Hrvatskoj tijekom socijalističkoga režima}

For almost half of a century, urban planning in Croatia took place under the socialist regime. During that time, it mostly played a role in addressing the pressing spacerelated issues of the development of socialist society, and in facilitating economic growth. In this paper, we examine urban planning in Croatia between 1944 and 1991 from eight aspects: the general roles of planning; legislation; relationship to societal planning; politicalinstitutional responsibility; urban planners and policy; plan execution; public participation; and environmental concerns. We analysed archival data and literature on urban, spatial and societal planning legislation and practices in the Socialist Republic of Croatia, including the planning journals Arbitektura and Coovjek $i$ prostor, and planning legislation from the socialist period. We outlined the five evolutionary phases over which urban planning experienced decentralisation from the federal to the communal level, advancements in public participation, and the involvement of environmental considerations in the decision-making process. We also studied the evolution of planning tools, which originated in the socialist period but remains in use today.

Key words: Croatia, general urban plans, planning legislation, socialist regime, urban planning
Gotovo pola stoljeća urbano planiranje u Hrvatskoj razvijalo se u okviru socijalističkoga režima. Ono je tijekom toga razdoblja uglavnom imalo ulogu rješavanja hitnih problema razvoja socijalističkoga režima vezanih za prostor i omogućavanja gospodarskoga rasta. Ovaj članak analizira urbano planiranje u Hrvatskoj između 1944. i 1991. godine kroz osam aspekata: opću zadaću planiranja u promatranoj etapi, zakonsku regulativu, odnos prema društvenom planiranju, političkoinstitucionalnu odgovornost, utjecaj urbanih planera na planersku praksu, provedbu planova, sudjelovanje javnosti i odnos prema okolišu. Analizirani su arhivski podatci i literatura o zakonodavstvu i praksi urbanoga, prostornoga i društvenoga planiranja u SR Hrvatskoj, uključujući planerske časopise Arbitekturu i Čorjek i prostor, kao i plansku legislativu iz socijalističkoga razdoblja. Definirano je pet razvojnih etapa kroz koje je urbano planiranje doživjelo decentralizaciju od federalne do razine općine (komune) te napredak glede sudjelovanja javnosti i razmatranja utjecaja na okoliš. Također je analiziran razvoj planskih alata nastalih tijekom socijalističkoga razdoblja, a koji su ostali u upotrebi do danas.

Ključne riječi: Hrvatska, generalni urbanistički planovi, zakonodavstvo planiranja, socijalistički režim, urbano planiranje 
HRVATSKI

GEOGRAFSKI

GLASNIK

81/2, 5-41 (2019.)

\section{Introduction}

Urban planning is one of the oldest and most omnipresent civilizational practices. It began with the first towns, but it only developed into a profession in the $19^{\text {th }}$ century - as a reaction to chaotic conditions in industrial cities (Hirt, 2005). It usually developed locally, underpinning development of industrial or military cities, and only in the $20^{\text {th }}$ century did it become regulated by national legislation. Notwithstanding its initial locally and (later, in the $20^{\text {th }}$ century) nationally regulated development, urban planning was often influenced by the practices and doctrines of influential planners, who pushed its progress forward in a particular region ${ }^{1}$. The process of development and maturation of urban planning in Croatia followed the same pattern. However, for almost half of the $20^{\text {th }}$ century, planning developed under different social, ideological, political and economic conditions after Croatia, then part of the second iteration of Yugoslavia, adopted socialism. Knowing the history of urban planning could reveal why cities are designed the way they are, how urban planning influenced their development, and how that legacy is reflected in their spatial structure and organisation today. Throughout the $20^{\text {th }}$ and $21^{\text {st }}$ centuries, historical studies of national urban planning systems have been written for many countries (npr. French and Hamilton, 1979; Schaffer, 1988; Corkindale, 1997; Wagenaar, 2011; Reiss, 2017). In Croatia, a few studies have covered or significantly touched upon urban planning of particular cities in certain periods (npr. Rubić, 1953; Perković, 1979; Magaš and Lončarić, 2006; Slukan Altić, 2006; 2012; Arbutina, 2007; Magaš, 2009; Došen, 2012; 2016; Kisić and Mlikota, 2017). To date, a comprehensive summary and synthesis of urban planning in Croatia has not been conducted.

This paper aims to stimulate the study of the history of urban planning in Croatia. It provides a systematic overview of the urban planning system in the Socialist Republic of Croatia (SR Croatia) between 1944 and 1991. The overview is based on a critical analysis of archival data and literature regarding urban, spatial, and societal planning legislation and practices in SR Croatia, supported by general histor-

\footnotetext{
1 E.g. German planner Josef Stübben and Austrian urbanist Camillo Sitte, who influenced urban planning in Europe in late $19^{\text {th }}$ and early $20^{\text {th }}$ centuries.
}

\section{Uvod}

Urbano planiranje jedna je od najstarijih i sveprisutnih civilizacijskih praksi. Nastalo je s pojavom prvih gradova premda se u profesiju razvilo tek u 19. stoljeću kao reakcija na kaotične uvjete u industrijskim gradovima (Hirt, 2005). Ponajprije se razvijalo lokalno, potpomažući razvoj industrijskih ili vojnih gradova, a tek je u 20. stoljeću zakonski regulirano na nacionalnoj razini. Unatoč inicijalno lokalnom i kasnije u 20. stoljeću nacionalno reguliranom razvoju urbano planiranje često se razvijalo pod utjecajem praksi i doktrina koje su uvodili utjecajni planeri u pojedinoj regiji, ${ }^{1}$ a koje su poticale njegov napredak. Proces razvoja i sazrijevanja urbanoga planiranja u Hrvatskoj slijedio je isti obrazac. Međutim, gotovo polovicu 20. stoljeća planiranje se razvijalo u drukčijim društvenim, ideološkim, političkim i ekonomskim uvjetima jer je u Hrvatskoj u okviru druge Jugoslavije vladao socijalizam. Poznavanje povijesti urbanoga planiranja može otkriti zašto su gradovi oblikovani na način na koji jesu, kako je to utjecalo na njihov razvoj i kako se ta ostavština danas odražava na njihovu prostornu strukturu i organizaciju. Kroz 20. i 21. stoljeće u mnogim su zemljama provedena povijesna istraživanja nacionalnih sustava urbanoga planiranja (npr. French i Hamilton, 1979; Schaffer, 1988; Corkindale, 1997; Wagenaar, 2011; Reiss, 2017). U Hrvatskoj je napisano tek nekoliko radova koji pokrivaju ili znatnije dotiču urbano planiranje pojedinih gradova u određenim razdobljima (npr. Rubić, 1953; Perković, 1979; Magaš i Lončarić, 2006; Slukan Altić, 2006; 2012; Arbutina, 2007; Magaš, 2009; Došen, 2012; 2016; Kisić i Mlikota, 2017) te do danas nisu provedeni obuhvatni pregled i sinteza urbanoga planiranja na nacionalnoj razini.

Namjera je ovoga članka potaknuti istraživanje povijesti urbanoga planiranja u Hrvatskoj, dajući produbljen pregled sustava urbanoga planiranja u Socijalističkoj Republici Hrvatskoj (SR Hrvatska) između 1944. i 1991. godine. Pregled se zasniva na kritičkoj analizi arhivskih podataka i literature o zakonodavstvu i praksi urbanoga, prostornoga i društvenoga planiranja u SR Hrvatskoj, potkrijepljenoj

\footnotetext{
1 Takvi su, primjerice, bili njemački planer Josef Stübben i austrijski urbanist Camillo Sitte koji su bitno utjecali na urbano planiranje u Europi u kasnom 19. i ranom 20. stoljeću.
} 
ical information. The archival data analysis entailed reviewing the planning journals Arbitektura (19471991) and Čovjek $i$ prostor (1954-1991), as well as urban, spatial, and societal planning legislation from the socialist period.

The period can be divided into five phases (Tab. 1). Within these phases, we considered the general role of planning, urban planning legislation, relationship to societal planning, political-institutional responsibility for urban planning, urban planners and policy, plan execution, public participation in urban planning, and environmental concerns. From the very beginning of the socialist period, urban planning played a role in most important contemporary undertakings, which will be analysed through each evolutionary phase. Urban planning legislation was a critical factor in determining these five phases as it had a profound impact on planning practices in the considered period. In relationship to societal planning, we analysed how urban planning fits into the overall socialist planning system and to what measure it retained independence from economic planning. Societal planning (drusttveno planiranje) was one of the fundamental features of Yugoslav socialism. In contrast to social planning, which is usually considered to be directing the social development of a community (Piha, 1973) and programming for selected social goals (Dyckman, 1966; Peattie, 1981), societal planning in Yugoslavia was concerned with directing economic development (Piha, 1973). The distinction is much more pronounced than the linguistic difference suggests and for the sake of distinguishing this importance difference, we use the term "societal planning" over "social planning" throughout the paper.

Furthermore, we analysed political-institutional responsibility for urban planning, which means the basic level at which planning is conducted as well as the institutions at different levels that were responsible for the facilitation of planning. In urban planners and policy, we investigated how urban planners and professional planning organisations affected planning policy at the level of the republic and, where relevant, the local level. We also examined plan execution as legislation tended to prescribe the planning process but not the implementation nor financing of planned interventions. Since public participation began to be općim povijesnim podatcima. Analiza arhivskih podataka uključivala je pregled prostornoplanerskih časopisa Arbitektura (1947. - 1991.) i Čorjek i prostor (1954. - 1991.) kao i zakona o urbanom, prostornom i društvenom planiranju u socijalističkom razdoblju.

Istraživano razdoblje može se podijeliti na pet etapa (tab. 1). U svakoj od njih razmatrani su opća uloga planiranja, urbanoplanska zakonska regulativa, odnos prema društvenom planiranju, političko-institucionalna nadležnost nad urbanim planiranjem, utjecaj urbanih planera na planersku praksu, provedba planova, sudjelovanje javnosti u urbanom planiranju i njegov okolišni aspekt. Od samih početaka socijalističkoga razdoblja urbano planiranje imalo je svoju ulogu u tada najvažnijim režimskim nastojanjima i ta je uloga analizirana kroz sve razvojne etape. Zakonska regulativa urbanoga planiranja bila je ključni čimbenik za definiranje pet razvojnih etapa s obzirom na njezin utjecaj na planersku praksu. Kroz odnos prema društvenom planiranju analizirana je pozicija urbanoga planiranja u cjelokupnom socijalističkom sustavu planiranja uključujući i to u kojoj je mjeri ono ostalo neovisno o ekonomskom planiranju. Društveno planiranje bilo je jedno od temeljnih obilježja jugoslavenskoga socijalizma. Za razliku od socijalnoga planiranja, koje se uobičajeno shvaća kao usmjeravanje socijalnoga razvoja zajednice (Piha, 1973), odnosno programiranje za odabrane socijalne ciljeve (Dyckman, 1966; Peattie, 1981), društveno planiranje u Jugoslaviji služilo je prije svega za usmjeravanje gospodarskoga razvoja (Piha, 1973). Diferencijacija je, dakle, mnogo izraženija nego što to sugerira jezična razlika te se u članku koristi pojam „društveno planiranje” za vid planiranja koji je u Jugoslaviji bio poznat pod tim nazivom.

Nadalje, analizirana je političko-institucionalna odgovornost za urbano planiranje što podrazumijeva osnovnu razinu na kojoj se planiranje provodilo kao i ustanove na različitim razinama odgovorne za provedbu i podršku planiranju. Pod utjecajem urbanih planera na planersku praksu istraženo je kako su urbani planeri i stručne planske organizacije utjecali na politike i prakse planiranja na republičkoj i, gdje je relevantno, lokalnoj razini u pojedinoj etapi. Također je analizirana provedba planova s obzirom na to da je legislativa često propisivala planski proces, ali ne i implementaciju i financiranje planiranih intervencija.
N. Tandarić

C. Watkins

C. D. Ives

Urban planning in socialist Croatia

Urbano planiranje u

Hrvatskoj tijekom socijalističkoga režima 
GEOGRAFSKI

GLASNIK

$81 / 2,5-41(2019$.
Tab. 1 Overview of the five evolutionary phases of the socialist urban planning system in Croatia

Tab. 1. Pregled pet razvojnih faza socijalističkog urbanog planiranja u Hrvatskoj

\begin{tabular}{|c|c|c|c|c|c|}
\hline $\begin{array}{c}\text { Period } \\
\text { / Razdoblje }\end{array}$ & 1944-1949 & 1949-1961 & $1961-1973$ & 1973-1980 & 1980-1991 \\
\hline $\begin{array}{l}\text { Dominant } \\
\text { historical process } \\
\text { / Prevladavajući } \\
\text { povijesni process }\end{array}$ & $\begin{array}{l}\text { Post-war } \\
\text { reconstruction / } \\
\text { Poratna obnova }\end{array}$ & $\begin{array}{l}\text { Installation of } \\
\text { self-management } \\
\text { and communal } \\
\text { systems / Uspostava } \\
\text { samoupravljanja i } \\
\text { komunalnoga sustava }\end{array}$ & $\begin{array}{l}\text { Economic reform / } \\
\text { Ekonomska reforma }\end{array}$ & $\begin{array}{l}\text { Introduction of } \\
\text { confederalism } \\
\text { / Uvođenje } \\
\text { konfederalizma }\end{array}$ & $\begin{array}{l}\text { The beginning of the } \\
\text { regimes demise and } \\
\text { political and economic } \\
\text { transition / Početak } \\
\text { propasti režima te } \\
\text { političke i ekonomske } \\
\text { tranzicije }\end{array}$ \\
\hline $\begin{array}{l}\text { The general role of } \\
\text { planning / Opća } \\
\text { zadaća planiranja }\end{array}$ & $\begin{array}{l}\text { Professional assistance } \\
\text { in reconstruction } \\
\text { / Stručni doprinos } \\
\text { obnovi }\end{array}$ & $\begin{array}{l}\text { Supporting economic } \\
\text { growth and } \\
\text { satisfying housing } \\
\text { needs / Potpora } \\
\text { gospodarskom } \\
\text { rastu i zadovoljenju } \\
\text { stambenih potreba }\end{array}$ & $\begin{array}{l}\text { Supporting economic } \\
\text { growth and facilitating } \\
\text { the spatial expansion } \\
\text { of cities / Potpora } \\
\text { gospodarskom rastu i } \\
\text { planiranje prostorne } \\
\text { ekspanzije gradova }\end{array}$ & $\begin{array}{l}\text { Supporting long-term } \\
\text { socio-economic } \\
\text { development / } \\
\text { Potpora dugoročnom } \\
\text { socioekonomskom } \\
\text { razvoju }\end{array}$ & $\begin{array}{l}\text { Facilitating urban } \\
\text { development } \\
\text { through renewal } \\
\text { and investments / } \\
\text { Planiranje urbanoga } \\
\text { razvoja kroz obnovu i } \\
\text { investicije }\end{array}$ \\
\hline $\begin{array}{l}\text { Political-institutional } \\
\text { responsibility } \\
\text { / Političko- } \\
\text { institucionalna } \\
\text { nadležnost }\end{array}$ & $\begin{array}{l}\text { Federal/ republic / } \\
\text { Federalna/republička }\end{array}$ & $\begin{array}{l}\text { Republic/communal } \\
\text { / Republička/ } \\
\text { komunalna }\end{array}$ & $\begin{array}{l}\text { Communal / } \\
\text { Komunalna }\end{array}$ & $\begin{array}{l}\text { Communal/republic } \\
\text { / Komunalna/ } \\
\text { republička }\end{array}$ & $\begin{array}{l}\text { Communal/republic } \\
\text { / Komunalna/ } \\
\text { republička }\end{array}$ \\
\hline $\begin{array}{l}\text { Legislation / } \\
\text { Zakonska regulativa }\end{array}$ & None / Ne postoji & $\begin{array}{l}\text { Basic Regulation } \\
\text { on General Urban } \\
\text { Plan / Osnovna } \\
\text { uredba o generalnom } \\
\text { urbanističkom planu } \\
\text { (S1.1.78/49) }\end{array}$ & $\begin{array}{l}\text { Urban and Regional } \\
\text { Spatial Planning } \\
\text { Act / Zakon o } \\
\text { urbanističkom } \\
\text { i regionalnom } \\
\text { prostornom planiranju } \\
\text { (NN 21/61) }\end{array}$ & $\begin{array}{l}\text { Physical Planning } \\
\text { and Construction } \\
\text { Land Use Act / } \\
\text { Zakon o prostornom } \\
\text { planiranju i korištenju } \\
\text { građevinskog zemljišta } \\
\text { (NN 14/73) }\end{array}$ & $\begin{array}{l}\text { Physical Planning and } \\
\text { Spatial Organisation } \\
\text { Act / Zakon o } \\
\text { prostornom planiranju } \\
\text { i uredivanju prostora } \\
\text { (NN 54/80) }\end{array}$ \\
\hline $\begin{array}{l}\text { Relation to societal } \\
\text { planning / Veza } \\
\text { s društvenim } \\
\text { planiranjem }\end{array}$ & $\begin{array}{l}\text { No explicit societal } \\
\text { planning to date / } \\
\text { Još nema izričita } \\
\text { društvenoga planiranja }\end{array}$ & $\begin{array}{l}\text { Urban planning } \\
\text { subordinated to } \\
\text { societal planning } \\
\text { in theory / Urbano } \\
\text { planiranje je u } \\
\text { teoriji podređeno } \\
\text { društvenom planiranju }\end{array}$ & $\begin{array}{l}\text { Urban planning is part } \\
\text { of societal planning / } \\
\text { Urbano planiranje je } \\
\text { sastavnica društvenoga } \\
\text { planiranja }\end{array}$ & $\begin{array}{l}\text { Urban planning is part } \\
\text { of societal planning / } \\
\text { Urbano planiranje je } \\
\text { sastavnica društvenoga } \\
\text { planiranja }\end{array}$ & $\begin{array}{l}\text { Urban planning is part } \\
\text { of societal planning / } \\
\text { Urbano planiranje je } \\
\text { sastavnica društvenoga } \\
\text { planiranja }\end{array}$ \\
\hline $\begin{array}{l}\text { Urban planners } \\
\text { and policy/Urbani } \\
\text { planeri i planerska } \\
\text { praksa }\end{array}$ & $\begin{array}{l}\text { Planners } \\
\text { (predominantly } \\
\text { architects) direct } \\
\text { reconstruction } \\
\text { plans and projects / } \\
\text { Planeri (uglavnom } \\
\text { arhitekti) reguliraju } \\
\text { planove i projekte } \\
\text { rekonstrukcije }\end{array}$ & $\begin{array}{l}\text { Planners } \\
\text { (predominantly } \\
\text { architects) initiate } \\
\text { the implementation } \\
\text { of regional planning } \\
\text { / Planeri (uglavnom } \\
\text { arhitekti) iniciraju } \\
\text { uvođenje regionalnoga } \\
\text { planiranja }\end{array}$ & $\begin{array}{l}\text { Planning } \\
\text { organisations become } \\
\text { multidisciplinary } \\
\text { / Planerske } \\
\text { organizacije postaju } \\
\text { multidisciplinarne }\end{array}$ & $\begin{array}{l}\text { Consolidation of } \\
\text { multidisciplinarity } \\
\text { and consultant } \\
\text { services / Učvršcivanje } \\
\text { multidisciplinarnosti i } \\
\text { konzultantskih usluga }\end{array}$ & $\begin{array}{l}\text { Planners reassess } \\
\text { earlier ambitious } \\
\text { plans and turn to } \\
\text { rationalisation / } \\
\text { Planeri preispituju } \\
\text { ambiciozne ranije } \\
\text { planove i okreću se } \\
\text { racionalizaciji }\end{array}$ \\
\hline $\begin{array}{l}\text { Plan execution / } \\
\text { Provedba planova }\end{array}$ & $\begin{array}{l}\text { Via labour actions and } \\
\text { private capital / Kroz } \\
\text { radne akcije i privatni } \\
\text { kapital }\end{array}$ & $\begin{array}{l}\text { Tolerated informal } \\
\text { construction hinders } \\
\text { plan execution / } \\
\text { Tolerirana ilegalna } \\
\text { gradnja otežava } \\
\text { provedbu planova }\end{array}$ & $\begin{array}{l}\text { Tolerated informal } \\
\text { construction hinders } \\
\text { plan execution / } \\
\text { Tolerirana ilegalna } \\
\text { gradnja otežava } \\
\text { provedbu planova }\end{array}$ & $\begin{array}{l}\text { Tolerated informal } \\
\text { construction hinders } \\
\text { plan execution / } \\
\text { Tolerirana ilegalna } \\
\text { gradnja otežava } \\
\text { provedbu planova }\end{array}$ & $\begin{array}{l}\text { Investors' interests } \\
\text { often given advantage } \\
\text { over plans / } \\
\text { Interesima investitora } \\
\text { često je dana prednost } \\
\text { pred planovima }\end{array}$ \\
\hline $\begin{array}{l}\text { Public participation / } \\
\text { Sudjelovanje javnosti }\end{array}$ & None / Ne postoji & $\begin{array}{l}\text { Public display of gups } \\
\text { introduced / Uvedeno } \\
\text { stavljanje GUP-a na } \\
\text { javni uvid }\end{array}$ & $\begin{array}{l}\text { Compulsory public } \\
\text { display of plan } \\
\text { proposals; groups' } \\
\text { remarks valued over } \\
\text { individuals' remarks } \\
\text { / Obvezno stavljanje } \\
\text { prijedloga plana na } \\
\text { javni uvid; prednost } \\
\text { primjedbama } \\
\text { socijalnih skupina } \\
\text { pred osobnim } \\
\text { primjedbama } \\
\end{array}$ & $\begin{array}{l}\text { Compulsory } \\
\text { public display of } \\
\text { plan proposals; } \\
\text { strengthened the role } \\
\text { of local communities } \\
\text { / Obvezno stavljanje } \\
\text { prijedloga plana na } \\
\text { javni uvid; osnažena } \\
\text { uloga mjesnih } \\
\text { zajednica }\end{array}$ & $\begin{array}{l}\text { Compulsory } \\
\text { public display of } \\
\text { plan proposals; } \\
\text { strengthened the role } \\
\text { of local communities } \\
\text { / Obvezno stavljanje } \\
\text { prijedloga plana na } \\
\text { javni uvid; osnažena } \\
\text { uloga mjesnih } \\
\text { zajednica }\end{array}$ \\
\hline $\begin{array}{l}\text { Environmental } \\
\text { concerns / Okolišni } \\
\text { aspekt }\end{array}$ & $\begin{array}{l}\text { No explicit } \\
\text { considerations / Nije } \\
\text { eksplicitno razmatran }\end{array}$ & $\begin{array}{l}\text { No explicit } \\
\text { considerations in } \\
\text { legislation / Nije } \\
\text { izričito razmatran u } \\
\text { zakonu }\end{array}$ & $\begin{array}{l}\text { Vaguely addressed } \\
\text { in legislation; left } \\
\text { to planners for } \\
\text { consideration / } \\
\text { Neodređeno definiran } \\
\text { u zakonu; odluka } \\
\text { o tretiranju na } \\
\text { planerima }\end{array}$ & $\begin{array}{l}\text { Extensive } \\
\text { considerations } \\
\text { in legislation; } \\
\text { questionable } \\
\text { implementation / } \\
\text { Ekstenzivno reguliran } \\
\text { u zakonu, no upitna } \\
\text { implementacija }\end{array}$ & $\begin{array}{l}\text { Extensive } \\
\text { considerations } \\
\text { in legislation } \\
\text { implementation } \\
\text { / Implementacija } \\
\text { ekstenzivno regulirana } \\
\text { zakonom }\end{array}$ \\
\hline
\end{tabular}


practised in western planning systems in the second half of the $20^{\text {th }}$ century, we examined the extent to which that also happened in the Yugoslav system. Finally, we reviewed the environmental concerns considered in planning legislation, urban plans, and their implementation.

\section{Legacy of urban planning from pre-socialist period}

Early traces of urban planning in Croatian territory date back to Roman coastal settlements (Vresk, 1990). Early town regulations of Dubrovnik from 1272 have also survived, but these are the exception (Salaj, 1988). Ottoman expansion between the $16^{\text {th }}$ and $18^{\text {th }}$ centuries introduced defensive town planning and several fortified cities with regular plans were built, e.g. Karlovac, Bjelovar, Koprivnica (Slukan Altić, 2006; Krajnik, 2015).

Formal planning began in the $19^{\text {th }}$ century. The introduction of railways to central Croatia and the Croatian Littoral boosted industrialisation, which in turn caused rapid urban growth. Consequently, regulation plans were introduced as a new planning tool (Blau and Rupnik, 2007). For the first time, these plans considered the whole area of a city and planned locations for expansion and the layout of infrastructural systems such as the water supply, sewage, and gas. Regular networks of blocks and streets were introduced along with the German practice of functional zoning of city areas for residential, industrial, commercial, and other purposes (Blau and Rupnik, 2007). In general, Croatian urban planning of the $19^{\text {th }}$ century was strongly influenced by theories from the prominent Central European planning schools, with planners schooled in cities of Austria-Hungary and Germany (Slukan Altić, 2012).

The post-First-World-War period saw continued urban growth and technological progress in transport systems which enabled stronger functional connections between cities and their regions. This presented new challenges for urban planning (Marinović-Uzelac, 2001). Furthermore, the legal unification between the more-developed northern and less-developed southern parts of Croatia, which reflected the situation throughout the whole
Kako se sudjelovanje javnosti počelo prakticirati u zapadnim sustavima planiranja kroz drugu polovicu 20. stoljeća, razmotreno je do koje se mjere to zbivalo u jugoslavenskom sustavu. Konačno, analizirano je kako su i koliko okolišni aspekti uzimani u obzir u planskoj legislativi, dokumentima i njihovoj implementaciji.

\section{Ostavština urbanoga planiranja iz predsocijalističkoga razdoblja}

Rani tragovi urbanoga planiranja na teritoriju $\mathrm{Hr}-$ vatske potječu iz rimskih naselja na Jadranskoj obali (Vresk, 1990). Najranije očuvane regulacije gradova potječu iz 1272. godine iz Dubrovnika, no one su prije iznimka nego pravilo (Salaj, 1988). Osmanlijska osvajanja između 16. i 18. stoljeća dovela su do uvođenja obrambenoga urbanog planiranja te je u Hrvatskoj izgrađeno nekoliko utvrđenih gradova s pravilnom strukturom, primjerice Karlovac, Bjelovar, Koprivnica (Slukan Altić, 2006; Krajnik, 2015).

Formalno planiranje započelo je u 19. stoljeću. Pojava željeznice u kontinentalnoj Hrvatskoj i primorju potaknula je industrijalizaciju koja je pak uzrokovala snažan urbani razvoj. Posljedično su kao planski alati uvedeni regulacijski planovi (Blau i Rupnik, 2007). Ti su planovi po prvi put razmatrali čitav teritorij grada s predviđenim lokacijama za njegovo širenje kao i trase za komunalnu infrastrukturu (vodovodna, kanalizacijska i kasnije plinovodna mreža). Pravilan raster blokova i ulica uveden je zajedno s njemačkom praksom funkcionalnoga zoniranja grada za stambene, industrijske, komercijalne i druge svrhe (Blau i Rupnik, 2007). Općenito je hrvatsko urbano planiranje u 19. stoljeću bilo pod snažnim utjecajem prominentnih srednjoeuropskih škola planiranja, a planeri su se školovali u velikim gradovima Austrougarske i Njemačke (Slukan Altić, 2012).

Urbani razvoj i tehnološki napredak u prometnim sustavima nastavili su se i nakon Prvoga svjetskog rata te omogućili snažno funkcionalno povezivanje gradova s njihovim okolicama, što je pred urbano planiranje postavilo nove izazove (Marinović-Uzelac, 2001). Štoviše, službeno ujedinjenje razvijenijega sjevera i slabije razvijenoga juga Hrvatske, slično kao i na razini čitave prve Jugoslavije, zahtijevalo je drukčije pristupe planiranju i gradova i regija. Ko-
N. Tandarić

C. Watkins

C. D. Ives

Urban planning in socialist Croatia

Urbano planiranje u

Hrvatskoj tijekom socijalističkoga režima 
of the Kingdom of (SHS) Yugoslavia, demanded different approaches in planning both cities and regions. Urban planning eventually became regulated at the state level under the 1931 Building Act, which was formulated under the influence of Western concepts (Dabović et al., 2017). The act was considered progressive and influenced later socialist planning legislation (Marinović-Uzelac, 2001). Croatian architects and urban planners were linked with broader European ideas (Franković, 1985) and gained authority and influence (Nedović-Budić and Cavrić, 2006). Based on the new act, the first international call for development of a new regulatory plan for Zagreb was carried out. The new plan represented an exemplary modernist urban plan based on functionalist concepts (Franković, 1985; Knežević, 2007). The Second World War caused enormous damage to many cities, some being largely destroyed (Zadar, Slavonski Brod), and disrupted planning activities.

\section{Early socialist urban planning (1944-1949)}

The Second World War left the territory of Croatia devastated, and in urgent need of physical and economic restoration (Grbić, 1975; Magaš, 2013; Glamuzina and Fuerst-Bjeliš, 2015). The communist party outlined three pressing objectives: postwar reconstruction; industrialisation; and electrification. Following the Soviet model, these were transformed into the first five-year plan in 1946 (1947-1952), aiming to induce economic growth and create income for the state budget in order to finance further projects. The lack of capital for financing large projects was compensated with voluntary work, mainly through "Labour Actions", and mandatory contributions for industrialisation by farmers - the predominant social group (Glamuzina and Fuerst-Bjeliš, 2015). While the primary focus of the socialist government was economic development, urban planners were given an important role in directing the reconstruction and planning of cities to support economic development. At that point, only around one-fifth of Yugoslavians lived in cities, but that share started rising rapidly along with industrialisation (Žuljić, 1975). načno je 1931. godine prvi put urbano planiranje zakonski regulirano na razini države donošenjem Građevinskoga zakona Kraljevine Jugoslavije koji je formuliran pod utjecajem zapadnjačkih planskih koncepata (Dabović i dr., 2017). Zakon je smatran naprednim za to doba i utjecao je na kasnije socijalističke planske zakone (Marinović-Uzelac, 2001). Hrvatski arhitekti i urbani planeri toga doba bili su uključeni u sva relevantna zbivanja u Europi (Franković, 1985) te su izgradili snažan autoritet $\mathrm{u}$ jugoslavenskom planskom sustavu (Nedović-Budić i Cavrić, 2006). Prema novom je zakonu proveden prvi međunarodni natječaj za izradu nove regulatorne osnove Zagreba koja je predstavljala egzemplarni modernistički urbani plan baziran na funkcionalističkim koncepcijama (Franković, 1985; Knežević, 2007). U Drugom svjetskom ratu mnogi su gradovi pretrpjeli izrazite štete, pojedini su u znatnoj mjeri razoreni (Zadar, Slavonski Brod), a planske aktivnosti bile su potpuno prekinute.

\section{Rano socijalističko urbano planiranje (1944. - 1949.)}

Izravna posljedica Drugoga svjetskog rata u $\mathrm{Hr}^{-}$ vatskoj bio je devastirani teritorij koji je zahtijevao hitnu fizičku i ekonomsku obnovu (Grbić, 1975; Magaš, 2013; Glamuzina i Fuerst-Bjeliš, 2015). Odmah po dolasku na vlast Komunistička partija Jugoslavije definirala je tri glavna cilja: poratnu obnovu, industrijalizaciju i elektrifikaciju države. Slijedeći sovjetski model, ti su ciljevi 1946. pretvoreni u prvi petogodišnji plan (1947. - 1952.) koji je za cilj imao potaknuti gospodarski razvoj i stvoriti dotok sredstava u državni proračun kojim će se financirati daljnji projekti. Nedostatak kapitala za financiranje velikih projekata kompenziran je dobrovoljnim radom, uglavnom radnim akcijama te obveznim doprinosima za industrijalizaciju od strane poljoprivrednika koji su bili prevladavajuća društvena skupina (Glamuzina i Fuerst-Bjeliš, 2015). Dok je primarni fokus socijalističke vlasti bio na gospodarskom razvoju, urbani planeri dobili su zadaću usmjeravati obnovu i razvoj gradova koji će podržati planirani gospodarski rast. U to je doba tek petina jugoslavenskoga stanovništva živjela u gradovima iako je taj broj počeo naglo rasti s industrijalizacijom (Žuljić, 1975). 
During its first five years, the socialist regime drew heavily on inherited planning legislation. The inter-war act was considered a good guide with established planning rules regulations, which could be implemented to avoid uncontrolled building development (Premerl, 1986). However, the existing legislation could not ensure strict implementation of urban planning principles because of the fast pace of reconstruction and development. On the other hand, there were very few trained planners and little time available for drafting new comprehensive urban plans (Piha, 1973) and even those that had been drafted were seen by some to hinder construction (Premužić, 1962).

Although there was no new planning legislation, two other laws had a profound impact on planning in that period. Already in 1944, the federal government adopted an act that converted all state property into people's property (Vlada DFJ, 1945). In cities, these were mainly public and administrative spaces which became subject to public redevelopment projects such as the reconstruction of parks, squares, children playgrounds, and thoroughfares. Another was the Expropriation Act (Vlada FNRJ, 1947), which allowed the expropriation of private property in the "people's interest", especially for the construction of factories, residential buildings, playgrounds, and other social objects.

\section{Relation to societal planning}

While not yet named as such, or by any other name, in this period societal planning was introduced indirectly through regional policy, oriented toward equalising the economic disparity among republics (Burton et al., 1966). Urban planners at the time were not directly engaged with societal planning, despite being occupied with defining the spatial structure and functions of cities to facilitate economic development.

\section{Political-institutional responsibility}

In the immediate post-war period, Yugoslavia followed the Soviet pattern: planning was organised as

\section{Zakonodavstvo}

Tijekom prvih pet godina socijalistički se režim značajno oslanjao na naslijeđeno zakonodavstvo urbanoga planiranja. Međuratni je zakon smatran dobrom osnovom u smislu postavljenih pravila planiranja koja su se mogla nastaviti primjenjivati da se izbjegne nekontrolirana gradnja (Premerl, 1986). Ta legislativa, međutim, nije mogla koordinirati načela planiranja s brzim tempom obnove i razvoja. Uz to, broj obučenih planera bio je malen kao i vrijeme dostupno za izradu novih obuhvatnih urbanih planova (Piha, 1973), a čak su i one planove koji se jesu izrađivali investitori često smatrali zaprekom za obnovu i gradnju (Premužić, 1962).

Iako nije bilo zakona o planiranju, druga dva zakona imala su značajan utjecaj na planiranje u ovoj etapi. Već 1944. savezna je vlada usvojila zakon kojim je sva državna imovina pretvorena u narodnu imovinu (Vlada DFJ, 1945). U gradovima su to uglavnom bile javne i administrativne površine koje su tako postale poligoni za projekte obnove i nove izgradnje, prvenstveno parkova, trgova, dječjih igrališta i prometnica. Drugi je bio Osnovni zakon o eksproprijaciji (Vlada FNRJ, 1947) koji je omogućio izvlaštenje privatnoga vlasništva u „narodnom interesu”, posebice za izgradnju tvornica, stambenih zgrada, igrališta i drugih društvenih objekata.

\section{Odnos prema društvenom planiranju}

Iako ne pod tim nazivom, u ovoj najranijoj etapi društveno je planiranje uvedeno neizravno kroz regionalnu politiku usmjerenu na ujednačavanje gospodarskih dispariteta među republikama (Burton i dr., 1966). Urbani planeri nisu bili izravno uključeni $\mathrm{u}$ društveno planiranje premda su definirali prostornu strukturu i funkcije gradova u svrhu njihova gospodarskoga razvoja.

\section{Političko-institucionalna nadležnost}

Neposredno nakon rata Jugoslavija je usvojila sovjetski model upravljanja u kojem je planiranje
N. Tandarić

C. Watkins

C. D. Ives

Urban planning in socialist Croatia

Urbano planiranje u

Hrvatskoj tijekom socijalističkoga režima 
a republic's responsibility although the decisions were made and delegated by the federal government (Burton et. al., 1966). The Department for Urban Planning was established in the Croatian Ministry of Construction in 1945, and this was followed by the founding of the Urban Planning Institute of Croatia (UPIC) in 1947, with branches in Zagreb, Split, and Rijeka (Premužić, 1962; Vresk, 1990; Bojić, 2018). The main task of urban planning institutes was to provide regulation plans and baseline studies for reconstruction. When that was not possible, they attempted to at least develop regulation sketches that took existing needs into account (Premužić, 1949). In the first few years, the UPIC created regulation planning documents for more than forty Croatian cities and towns (Salaj, 1988).

The working conditions in the UPIC were poor. The Institute employed fourteen people out of which seven were expert architects who had to cover the needs of all Croatian cities and towns (Premužić, 1962). The only possible mode of working in such settings was a "walk-in" approach where planners received investors with project plans and made planning permission decisions. Furthermore, for most tasks, there were no required and validated data (Petrović, 1954; Premužić, 1962). In 1948, research became one of UPIC's main responsibilities, with the aims of advancing urbanism in Croatia, creating urban planning policies, and training new generations of urban planners (Premužić, 1962).

\section{Urban planners and policy}

It was mainly planners from the pre-war period who led the post-war revival of urban planning in Yugoslavia. Despite the dominant socialist ideology, Croatian planners and architects remained committed to international modernism rather than socialist realism, which had taken over throughout the Central and Eastern Europe (Blau and Rupnik, 2007). One of the re-initialising events was the urban planning seminar held in Šibenik in 1944, where planners and other interested parties discussed the renovation of cities, towns, and villages and defined certain guidelines (Kranjčević, 2009). The Architecture Department of the Technical Faculty of Zagreb played an important role in the development of urban and spatial planning training professionals in urban planning and post-war renewal (Vresk, 1990). bilo u nadležnosti republika iako su se odluke donosile i delegirale na federalnoj razini (Burton i dr., 1966). Odsjek za urbanizam osnovan je pri Ministarstvu građevina već 1945., a dvije godine kasnije osnovan je i Urbanistički institut Hrvatske (UIH) s ograncima u Zagrebu, Splitu i Rijeci (Premužić, 1962; Vresk, 1990; Bojić, 2018). Osnovni je zadatak urbanističkih instituta bio izrada regulacijskih planova i studija obnove, a kada to nije bilo moguće, onda u najmanju ruku regulacijskih skica sukladno postojećim potrebama (Premužić, 1949). U prvih je nekoliko godina UIH izradio regulacijske planove za više od četrdeset hrvatskih gradova (Salaj, 1988).

Radni uvjeti u UIH-u bili su razmjerno loši. Institut je zapošljavao četrnaest osoba od kojih sedam stručnjaka - arhitekata koji su morali pokriti potrebe svih hrvatskih gradova (Premužić, 1962). Jedini mogući oblik rada u takvim je uvjetima bio ambulatorni način u kojem su planeri primali investitore s projektnim planovima i izdavali im lokacijske dozvole. Uz sve to, za većinu zadataka nije bilo potrebnih ni provjerenih podataka (Petrović, 1954; Premužić, 1962). Godine 1948. jedna od UIH-ovih zadaća postao je istraživački rad s ciljem unaprjeđenja urbanizma u Hrvatskoj, stvaranja urbanoplanskih politika i osposobljavanja novih naraštaja urbanih planera (Premužić, 1962).

\section{Urbani planeri i planerska praksa}

Oživljavanje urbanoga planiranja u Jugoslaviji vodili su uglavnom planeri iz predratnoga razdoblja. Usprkos dominantnoj socijalističkoj ideologiji hrvatski planeri i arhitekti ostali su predani internacionalnom modernizmu radije nego socijalističkom realizmu koji je zavladao Središnjom i Istočnom Europom (Blau i Rupnik, 2007). Jedan od prvih događaja oživljavanja urbanizma održan je u Šibeniku 1944. godine i na njemu su planeri i drugi zainteresirani sudionici raspravljali o obnovi gradova i sela i smjernicama za nju (Kranjčević, 2009). Arhitektonski odjel Tehničkoga fakulteta u Zagrebu imao je važnu ulogu u razvoju urbanoga i prostornoga planiranja kroz osposobljavanje stručnjaka za urbano planiranje i poratnu obnovu (Vresk, 1990). 


\section{Public participation and plan execution}

Public participation in planning in this period was practically non-existent. Decisions were made mostly at the federal level and executed at the republic level. Due to the lack of funds from the federal budget, the government had to rely on other approaches for renovation and construction. The first such approach was to mobilise a labour force for the execution of plans and projects (Fig. 1). Unemployed youth and adults undertook work that did not require vocational skills (Glamuzina and Fuerst-Bjeliš, 2015) and in this way restoration progressed faster and the economy began to revive ${ }^{2}$.

Another approach was using private investor capital. However, under the conditions in a young Yugoslavia, investors only had enough funds for the construction of buildings while infrastructure (roads, water supply, sewage, etc.) and exterior spaces, which were part of original projects, were often postponed for the foreseeable future (Maretić, 1959). The urgent need for housing in cities was frequently in conflict with urban planning principles. In many cases, investors would propose temporary buildings, for which they could obtain building permits, but then they would, in fact, build permanent buildings. Such cases deceived the urban planning institutes and authorities that approved co-financing and meant that public funds were used to construct buildings in poor locations which hindered later urban development (Premužić, 1962).

\section{Environmental concerns}

In this early period, environmental concerns were not regulated nor explicitly considered. However, according to Ungar (1949), the 'war wounds' in public spaces created by the destruction of buildings and digging up bunkers, shelters, and trenches were remediated and often transformed into green spaces. Moreover, post-war reconstruction created new urban green spaces within the development

2 The establishment of labour actions did not have the sole goal of securing a cost-free labour force, it also had other functions among which two can be stressed: the creation of a sense of belonging to a cohesive multinational Yugoslav community and collaboration among youth from all around Yugoslavia which forged a sense of brotherhood and unity through shared experience (Baković, 2015).

\section{Sudjelovanje javnosti i provedba planova}

Sudjelovanje javnosti u planiranju u ovoj etapi praktički nije postojalo. Odluke su se donosile uglavnom na federalnoj razini i provodile na republičkoj. Zbog nedostatka sredstava iz federalnoga budžeta vlast se morala oslanjati na druge pristupe obnovi i gradnji. Prvi takav pristup bio je mobilizacija radne snage iz naroda za izvršenje planova i projekata (sl. 1). Nezaposleni mladi i odrasli radili su poslove koji nisu zahtijevali strukovne vještine (Glamuzina i Fuerst-Bjeliš, 2015) čime je ubrzana obnova i omogućeno oživljavanje gospodarstva. $^{2}$

Drugi je pristup bila mobilizacija privatnoga kapitala. Međutim, u ranim jugoslavenskim uvjetima investitori su obično imali dovoljno sredstava tek za gradnju zgrada, a izgradnja infrastrukture (ceste, vodovod, kanalizacija...) i uređenje eksterijera, koji su bili sastavni dio izvornoga projekta, često su odlagani za doglednu budućnost (Maretić, 1959). Neodložive potrebe za stanovima u gradovima učestalo su bile u sukobu s načelima urbanoga planiranja. U mnogo bi slučajeva investitori predložili privremenu zgradu za koju bi mogli dobiti dozvolu za gradnju, ali bi onda zapravo izgraditi trajnu zgradu. Takvi su slučajevi zavaravali urbanističke institute i vlasti koje bi odobrile sufinanciranje, a potom bi javna sredstva bila utrošena na gradnju zgrada na lošim lokacijama koje bi ometale daljnji urbanistički razvoj područja (Premužić, 1962).

\section{Okolišni aspekt}

U toj ranoj etapi okolišni aspekt planiranja nije bio reguliran ni eksplicitno razmatran. Međutim, prema Ungaru (1949) „ratne rane” na javnim površinama stvorene uništenjem zgrada, kopanjem bunkera, skloništa i jaraka sanirane su i nerijetko pretvarane u zelene površine. Štoviše, poratna obnova rezultirala je novim zelenim površinama u već izgrađenim dijelovima brzorastućih gradova. No

\footnotetext{
2 Naravno, uspostava radnih akcija nije imala za cilj isključivo osiguravanje besplatne radne snage, već i druge funkcije među kojima se posebno ističe stvaranje osjećaja pripadnosti objedinjenoj multinacionalnoj jugoslavenskoj zajednici i suradnja mladih iz različitih dijelova Jugoslavije kroz koje će se formirati osjećaj bratstva i jedinstva (Baković, 2015)
}

N. Tandarić

C. Watkins

C. D. Ives

Urban planning in socialist Croatia

Urbano planiranje u

Hrvatskoj tijekom socijalističkoga režima 


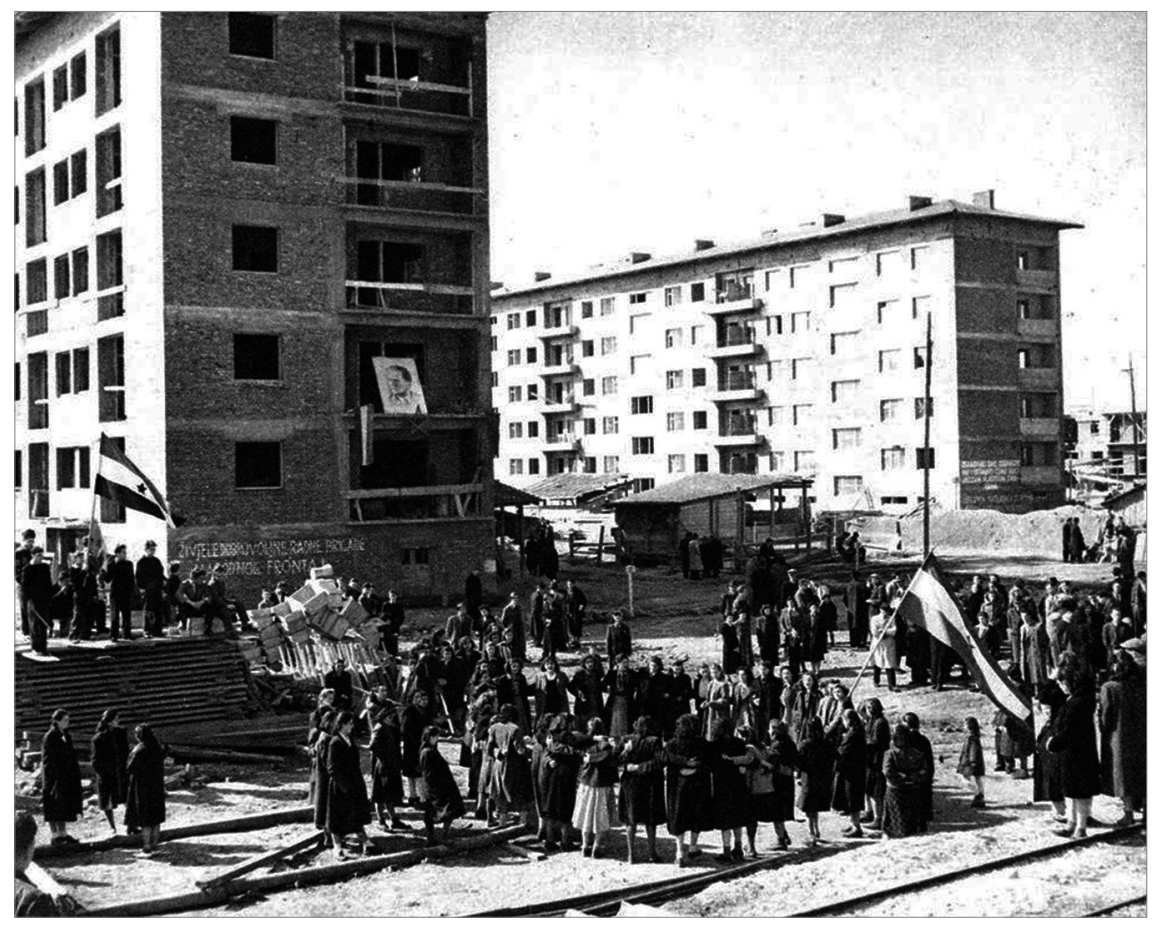

Fig. 1 Volunteer workers dancing during a break of a labour action for construction of new housing in Zagreb around 1950

SI. 1. Dobrovoljni radnici plešu kolo u pauzi radne akcije izgradnje stambene zgrade U Zagrebu oko 1950

Source: unknown author, private collection by Milan Vasić "Proleterskih brigada od broja 228 do 236 građene dobrovoljnim radom 1950./1951. godine" Izvor: nepoznat autor, privatna kolekcija Milana Vasića „Proleterskih brigada od broja 228 do 236 građene dobrovoljnim radom 1950./1951. godine" areas in rapidly growing towns. However, the design and layout of these areas was often neglected as greenery around buildings were considered a luxury that was usually postponed for more prosperous times (Premužić, 1962).

\section{The period of early planning legislation (1949-1961)}

The split between Tito and Stalin in $1948 \mathrm{rad}-$ ically changed the overall socialist policy in Yugoslavia, opening the way to what came to be known as Yugoslav socialism. In contrast to the centralised Soviet model, the Communist Party introduced the workers' self-management system from 1950 to 1952 as the first step towards decentralisation in all forms of governance and planning, especially economic planning (Grbić, 1975). Decentralisation was further strengthened by the introduction of the communal system in 1955. Via this reform, all wards, which were merely territorial units with negligible authorities, were transformed into communes. According to the Marxist vision of the 1871 Paris Commune (Marx et al., 2008), socialist communes were organised as complex political and socio-economic sub-regional communities with dizajn i struktura takvih površina često su zanemarivani s obzirom na to da se zelenilo oko zgrada smatralo luksuzom čije se ostvarenje obično odlagalo za neka prosperitetnija vremena (Premužić, 1962).

\section{Etapa rane planske legislative (1949. - 1961.)}

Raskol između Tita i Staljina 1948. radikalno je promijenio cjelokupnu socijalističku politiku u Jugoslaviji, otvarajući put prema jugoslavenskom socijalizmu. Za razliku od centraliziranoga sovjetskog modela, Komunistička je partija između 1950. i 1952. uvela sustav radničkoga samoupravljanja kao prvi korak prema decentralizaciji u svim oblicima upravljanja i planiranja, posebice ekonomskom planiranju (Grbić, 1975). Decentralizacija je dalje osnažena uvođenjem komunalnoga sustava 1955. Tom su reformom sve dotadašnje općine, koje su bile tek teritorijalne jedinice sa zanemarivim ovlastima, pretvorene u komune (iako je zadržan naziv općina). Prema marksističkoj viziji pariške komune iz 1871. (Marx i dr., 2008), socijalističke su komune organizirane kao političke i socioekonomske subregionalne zajednice sa samoupravnim ovlastima i vlastitim 
self-managing authorities and their own budgets (Fisher, 1965). The new system facilitated one of the most rapid rates of economic growth in the world in the 1950s (Horvat, 1966). The growth was concentrated mainly in urban areas and there was a huge influx of people from rural areas who often settled on the margins of cities (Magdalenić, 1971). The rapid urban growth, reflected by housing needs and industrial zones, necessitated great efforts in urban planning (Piha, 1973).

\section{Legislation}

The Basic Regulation on General Urban Plan (Vlada FNRJ, 1949) adopted in 1949 established the role of urban planning in the socio-economic system of Yugoslavia. Urban planning objectives had to support socio-economic development plans (Nedović-Budić and Cavrić, 2006), which indicated that the early socialist regime saw urban planning as an extension of economic planning. However, despite being based on Soviet political ideology, the Regulation was drafted following extensive consideration of western planning legislation, particularly German, French, English, Swedish, Dutch, and American. As a consequence, the Regulation combined Western planning principles with the socialist modernist approach resulting in planning the extensive construction of affordable residential buildings in cities (Nedović-Budić and Cavrić, 2006).

The 1949 Regulation introduced a general urban plan (GUP) or masterplan - the new urban planning instrument that would remain present in all future socialist and post-socialist legislation. Predating decentralisation reform, the act defined that city administrations were responsible for drafting and adopting urban plans, following approval from the Ministry of Communal Affairs. The systemic reforms of the 1950s relegated urban planning to lower levels. In practice that meant that republics took on the responsibility of issuing urban planning legislation and cities/communes drafted and adopted plans. As of the 1950s, each Yugoslav republic had its own legislative framework for planning (Simmie, 1989). Problems with the 1949 Regulation included the lack of prescribed physical budžetom (Fisher, 1965). Novi je sustav potpomogao jednu od najbrže rastućih stopa gospodarskoga rasta u svijetu 1950-ih (Horvat, 1966). Rast je bio koncentriran primarno u urbanim područjima gdje je bio i snažan dotok imigranata iz ruralnih područja koji su se često naseljavali na rubovima grada (Magdalenić, 1971). Rapidan gospodarski i urbani razvoj odrazili su se u golemim potrebama za stanovima i industrijskim zonama stavljajući velike izazove pred urbano planiranje (Piha, 1973).

\section{Zakonodavstvo}

Osnovna uredba o generalnom urbanom planu (Vlada FNRJ, 1949) usvojena 1949. službeno je ustanovila ulogu urbanoga planiranja u socioekonomskom sustavu Jugoslavije. Svrha je urbanoga planiranja bila potpora društveno-ekonomskim razvojnim planovima (Nedović-Budić i Cavrić, 2006), što upućuje na to da je rani socijalistički režim sagledavao urbano planiranje kao produženu ruku ekonomskoga planiranja. Iako je bila utemeljena na sovjetskoj političkoj ideologiji, spomenuta uredba formulirana je kroz ekstenzivne konzultacije sa zapadnjačkom planskom legislativom, prije svega njemačkom, francuskom, engleskom, švedskom, danskom i američkom. Uredba je dakle sjedinila zapadnjačka planska načela sa socijalističkim modernističkim pristupom što je rezultiralo opsežnom gradnjom povoljnih stambenih zgrada u gradovima (Nedović-Budić i Cavrić, 2006).

Uredbom iz 1949. uveden je generalni urbanistički plan (GUP) - novi planski instrument koji se zadržao u upotrebi kroz sve buduće socijalističke i postsocijalističke planske legislative. S obzirom na to da je donesena prije sistemskih reforma, uredbom je definirano da je gradska uprava odgovorna za izradu i usvajanje urbanističkih planova, uz prethodno odobrenje Ministarstva komunalnih poslova. Sistemske reforme iz 1950-ih spustile su planiranje na niže razine. $U$ praksi je to značilo da su republike preuzele odgovornost izrade urbanoplanske legislative dok su gradovi/općine trebali izrađivati i usvajati planove. Stoga je od 1950-ih svaka jugoslavenska republika imala svoj vlastiti zakonodavni okvir za planiranje (Simmie, 1989). Neki od problema ove uredbe bili su nedostatak
N. Tandarić

C. Watkins

C. D. Ives

Urban planning in socialist Croatia

Urbano planiranje $u$

Hrvatskoj tijekom socijalističkoga režima 
planning, such as land use plans and zoning ( $\mathrm{Ma}-$ rinović-Uzelac, 1989), and the scarcity of trained planners capable of producing high-quality plans (Premužić, 1962). Furthermore, a GUP was not able to regulate general construction, rather only capital objects and facilities (Piha, 1973).

Another law that had a profound impact on urban planning was the 1958 Nationalisation of Construction Land Act, according to which all developed and undeveloped land in cities and towns was nationalised and transformed into people's property (Skupština SFRJ, 1958; Anonymous, 1980). The aim was to facilitate societal and economic planning at the local level. However, the act created additional problems as buildings and other objects on nationalised land were not nationalised and communes were supposed to purchase these buildings if they sought to redevelop the land. This was a very significant obstacle for many towns (Simmie, 1989).

\section{Relation to societal planning}

Societal planning was formally introduced to Yugoslavia alongside the self-management system. It was founded on the presumption that planning is an economic and democratic right and obligation of the working class. Therefore political, social and economic governance should devolve to the level of local communities and enterprises (Dabović et al., 2017). While enterprises had to draft self-management plans, communes and republics planned their general socio-economic development through societal plans. In this new setting, urban planning was considered subordinate to societal planning and technically had the role of providing the physical spatial basis for socio-economic development at the local level (Dabović et al., 2017). Correspondingly, GUPs were now considered subordinate to societal plans and had to comply with them (Piha, 1973).

\section{Political-institutional responsibility}

Following the adoption of the new legislation, the new Administration for the General Urban Plan (AGUP) was founded within the Ministry of propisanoga fizičkog planiranja, poput planiranja namjene zemljišta i zoniranja (Marinović-Uzelac, 1989) te nedostatak osposobljenih planera koji bi mogli izrađivati toliko visokokvalitetnih planova (Premužić, 1962). Štoviše, GUP nije mogao regulirati sveopću gradnju, već samo kapitalne objekte i postrojenja (Piha, 1973).

Još jedan zakon koji je bitno utjecao na urbano planiranje bio je Zakon o nacionalizaciji najamnih zgrada i građevnih zemljišta iz 1958. kojim su sve izgrađene i neizgrađene površine u gradovima nacionalizirane i pretvorene u narodno vlasništvo (Skupština SFRJ, 1958; Anonymous, 1980). Cilj je bio olakšati društveno i ekonomsko planiranje na lokalnoj razini. U praksi je taj zakon stvorio dodatne probleme jer zgrade i drugi objekti na nacionaliziranom zemljištu nisu bili nacionalizirani te su gradovi morali otkupiti te objekte ako su htjeli prenamijeniti zemljište, što je mnogim gradovima bila krupna prepreka (Simmie, 1989).

\section{Odnos prema društvenom planiranju}

Društveno je planiranje formalno uvedeno u Jugoslaviji zajedno sa sustavom samoupravljanja. Utemeljeno je na pretpostavci da je planiranje ekonomsko i demokratsko pravo i obveza radničke klase. Stoga je političko, socijalno i ekonomsko upravljanje trebalo spustiti na razinu općina i poduzeća (Dabović i dr., 2017). Poduzeća su morala izrađivati samoupravne planove, a općine i republike planirale su svoj opći društveno-ekonomski razvoj kroz društvene planove. U novim uvjetima urbano se planiranje smatralo podređenim društvenom planiranju i tehnički je imalo ulogu pružanja fizičke prostorne osnove za socioekonomski razvoj na lokalnoj razini (Dabović i dr., 2017). Sukladno tomu, GUP-ovi su smatrani podređenima društvenim planovima i morali su biti usklađeni s njima (Piha, 1973).

\section{Političko-institucionalna nadležnosł}

Nakon usvajanja uredbe nova je Uprava za generalni urbanistički plan (UGUP) osnovana u Ministarstvu komunalnih poslova 1949. te je postala 
Communal Affairs in 1949, and the UPIC became subordinated to it (Premužić, 1962). The AGUP aimed to harmonise the planning process by establishing a system of collaboration between different levels of urban planning governance-from communes to UPIC. In practice, however, many communes supported the professionally questionable proposals of influential investors, not realising the long-term damage they could do to their cities or towns (Premužić, 1962).

Along with the systemic reform, the UPIC fell under the Governmental Secretariat for People's Economic Affairs' jurisdiction in 1953 (Premužić, 1962), only to be transformed in 1954 into an independent, self-managed institution operating outside of the administrative hierarchy. Moreover, its regional branches in Zagreb, Split and Rijeka all became responsible for their own financing and were contracted by communes and districts requiring professional assistance (Bojić, 2018). In a way, therefore, urban planning partly became a market-based activity.

The UPIC actively participated in planning tasks and solving urban planning problems across Croatia and Yugoslavia. It conducted urban planning studies and methodological research, drafted planning legislation, and contributed to the organisation of official urban planning (Premužić, 1962). In the 1950s, urban planning bureaus were founded in all republic capitals and many larger cities, and they drafted urban plans for their communes (Piha, 1973).

\section{Urban planners and policy}

Urban planning was still dominated by architects and plans often resembled architectural projects rather than comprehensive planning documents. However, professionals from other disciplines started being involved in planning at planning bureaus (Piha, 1973). The second half of the 1950s was characterised by the opening of Yugoslavia to the world (Premerl, 1986), which was reinforced by the establishment of the Non-Alignment Movement, which Yugoslavia helped found. A number of urban planners were trained abroad, nadređenom UIH-u (Premužić, 1962). Zadaća je UGUP-a bila usklađivanje planskoga procesa uspostavom sustava suradnje između različitih razina uprave nad urbanim planiranjem - od općina do UIH-a. U praksi su, međutim, mnoge općine dopuštale stručno upitne prijedloge utjecajnih investitora, ne shvaćajući dugoročnu štetu koju tako mogu uzrokovati svojim gradovima (Premužić, 1962).

Zajedno sa sistemskim reformama UIH je 1953. prešao u nadležnost vladina Sekretarijata za poslove narodne privrede (Premužić, 1962), a već sljedeće godine bio je pretvoren u nezavisnu, samoupravnu ustanovu koja je djelovala izvan republičke upravne hijerarhije. Istodobno su i UIH-ovi regionalni ogranci u Zagrebu, Splitu i Rijeci postali odgovorni za vlastito financiranje, odnosno financirali su se kroz ugovore s općinama i kotarima koji su trebali njihove profesionalne usluge (Bojić, 2018). Time su učinjeni prvi koraci pretvorbe urbanoga planiranja u tržišno-usmjerenu djelatnost.

UIH je vrlo aktivno sudjelovao u rješavanju gotovo svih važnijih urbanističkih problema i zadataka diljem Hrvatske i Jugoslavije. Provodio je urbanoplanske studije i metodološka istraživanja, izrađivao plansku legislativu i doprinosio ustrojavanju službenoga sustava urbanog planiranja (Premužić, 1962). Od 1950-ih počinju se osnivati urbanistički zavodi u svim republičkim glavnim gradovima kao i u više velikih gradova u Jugoslaviji, a njihov je cilj bio izrada urbanističkih planova za svoje općine (Piha, 1973).

\section{Urbani planeri i planerska praksa}

U urbanom planiranju u ovoj etapi još uvijek su prevladavali arhitekti te su planovi često više podsjećali na arhitektonske projekte nego na obuhvatne planske dokumente. No i stručnjaci iz drugih disciplina počeli su se zapošljavati u urbanističkim zavodima (Piha, 1973). Drugu polovicu 1950-ih obilježava otvaranje Jugoslavije svijetu (Premerl, 1986), što je posebno ojačano nakon osnivanja Pokreta nesvrstanih kojem je Tito bio jedan od utemeljitelja. Velik broj urbanih planera se i dalje školovao u inozemstvu - Engleskoj, Nizozemskoj,
N. Tandarić

C. Watkins

C. D. Ives

Urban planning in socialist Croatia

Urbano planiranje u

Hrvatskoj tijekom socijalističkoga režima 
in England, the Netherlands, Italy, the USA, Sweden, and Germany, continuing the tradition started in the pre-war period. Moreover, they often made professional visits to different European countries bringing new perspectives to domestic practice (Premužić, 1962).

The establishment of the Ordinary Conference of Yugoslav Urban Planners in 1952 had a substantial impact on the development of the profession. At the third conference in Ohrid, SR Macedonia in 1954, a delegation of urban planners met federal Vice-President Edvard Kardelj and proposed new legal arrangements for urban planning (Petrović, 1954). There were four main points: (1) urban planning should become a mandatory component of societal planning; (2) urban plans should arrange settlements and regions, thereby guiding economic growth; (3) urban plans should be developed for periods of several decades; (4) a comprehensive urban planning service should be established with urban planning councils at both republic and communal levels. The proposal was accepted and implemented over several years and the Urban Planning Committee was established within republic governments in 1955 (Bukvić, 2012).

Point 2 of the proposal indicated urban planners' interest in regional spatial planning. At the sixth conference in 1957, Croatian urban planners argued that the absence of a comprehensive physical planning system resulted in 'irrational' land use, functional spatial imbalances, missed economic opportunities, and a general decrease in quality of life (Nedović-Budić and Cavrić, 2006; Bojić, 2018). Consequently, the governmental Committee for Regional Planning was founded in 1960 and a year later the drafting of regional spatial plans became an official task of urban planning institutes (Premužić, 1962).

\section{Plan execution}

The implementation tools for GUP were prospective and current plans (Piha, 1973). After 1955, communes were responsible for the preparation and execution of both spatial and societal plans,
Italiji, Sjedinjenim Američkim Državama, Švedskoj i Njemačkoj, nastavljajući tradiciju započetu u predratnom razdoblju. Uz to su često organizirana stručna putovanja u razne europske zemlje koja su unosila nove poglede u domaće prakse planiranja (Premužić, 1962).

Osnivanje Redovnoga savjetovanja urbanista Jugoslavije 1952. imalo je značajan utjecaj na razvoj struke. $\mathrm{Na}$ trećem savjetovanju održanom 1954. u Ohridu u SR Makedoniji delegacija urbanih planera susrela se s federalnim potpredsjednikom Kardeljem i predložila novi službeni ustroj urbanističke službe (Petrović, 1954). Mogu se izdvojiti četiri glavne točke: (1) urbano planiranje treba postati obvezna sastavnica društvenoga planiranja; (2) urbanistički planovi trebaju uređivati naselja i regije omogućujući njihov gospodarski razvoj; (3) urbanistički planovi trebaju se izrađivati za razdoblja od nekoliko desetljeća; (4) treba se ustanoviti urbanistička služba s urbanističkim savjetima u narodnoj vlasti na republičkoj i općinskoj razini. Taj je prijedlog prihvaćen i počeo se uvoditi u narednim godinama te je 1955 . Odbor za urbanizam ustanovljen pri Izvršnom vijeću Sabora Narodne Republike Hrvatske (tadašnji naziv za vladu) (Bukvić, 2012).

Druga točka prijedloga pokazuje zanimanje urbanih planera za regionalno prostorno planiranje koje još nije bilo ustanovljeno. $\mathrm{Na}$ šestom savjetovanju održanom 1957. hrvatski urbani planeri argumentirali su da je odsustvo obuhvatnoga prostornoplanskog sustava rezultiralo „iracionalnom” namjenom zemljišta, funkcionalnim prostornim disbalansima, propuštenim gospodarskim prilikama i općim smanjenjem kvalitete života (Nedović-Budić i Cavrić, 2006; Bojić, 2018). Kao rezultat toga osnovan je 1960. Odbor za regionalno planiranje pri vladi, a godinu dana kasnije izrada regionalnih planova službeno je postala zadatak urbanističkih instituta (Premužić, 1962).

\section{Provedba planova}

Provedbeni alati GUP-a bili su perspektivni i tekući planovi (Piha, 1973). Nakon 1955. općine su postale odgovorne za pripremu i provedbu i prostornih i društvenih planova iako se ubrzo 
although it soon became obvious that many communes, especially smaller ones, were not up to the task (Burton et al., 1966). Moreover, decentralisation also brought lessened central control over planning and building standards. For instance, the official stance regarding the construction of workers' settlements was in favour of implementing the highest standards which involved functional neighbourhoods consisting of multi-flat buildings surrounded with green spaces (instead of individual houses), central supply centres, and restaurants (Premužić, 1962). But the demand for housing caused by the influx of people, combined with the lack of funds, meant standards were often relaxed (Maretić, 1959). Such informal settlements would be provided with public infrastructure in the same fashion as planned projects (Poropat et al., 2006). Moreover, both government inspectors and local authorities often turned a blind eye to this sort of unplanned development. Rogić (2006) speculates that the regime needed to be seen to be caring for all social groups, especially the edge groups. So as a reward for political support, the regime provided these groups higher living standards via guaranteed work and informal possibilities for access to housing. But this toleration of informal construction in the 1950s enabled its proliferation in subsequent decades (see Katurić, 2016).

\section{Public participation}

The 1949 Regulation did not oblige the plan-makers to engage the public although plans had to be on public display for one month. The latter transfer of planning responsibilities to the commune gave urban planners an opportunity to engage more with local authorities (Bojić, 2018). This did not mean wider engagement with the local public; indeed the local authorities were keener to receive the opinions of developers (Piha, 1973).

\section{Environmental concerns}

The new legislation did not mention environmental concerns, although some incentives towards pokazalo da mnoge od njih, posebice manje općine, nisu bile dorasle tom zadatku (Burton i dr., 1966). Štoviše, decentralizacija je donijela i slabiji nadzor republičkih tijela nad planskim i građevinskim standardima. Primjerice, službeni je stav oko izgradnje radničkih naselja podrazumijevao primjenu najviših standarda uključujući stvaranje funkcionalnih susjedstava koja se sastoje od zgrada s više stanova okruženih zelenilom (umjesto pojedinačnih kuća), središnjim opskrbnim centrom i restoranima (Premužić, 1962). No potražnja za stanovima uzrokovana snažnim dotokom ljudi u kombinaciji s nedostatkom sredstava značila je da su se standardi često zanemarivali u praksi ( $\mathrm{Ma}$ retić, 1959). Tako nastala "divlja” naselja vlasti bi svejedno opskrbile javnom infrastrukturom na isti način kao i odobrena projektirana naselja (Poropat i dr., 2006). Dapače, i službeni inspektor i lokalne vlasti često su okretali glavu na takvu gradnju. Rogić (2006) nagađa da je režim morao biti viđen kao da vodi brigu o svim društvenim skupinama, posebice onim rubnim. Stoga bi kao „nagradu” za političku potporu režim omogućio tim skupinama bolje životne uvjete kroz osigurani posao i neformalne mogućnosti za rješavanje stambenoga pitanja. Toleriranje divlje gradnje u 1950-ima je, međutim, omogućilo njezino bujanje u narednim desetljećima (npr. Katurić, 2016).

\section{Sudjelovanje javnosti}

Uredba iz 1949. nije obvezivala izrađivače planova na uključivanje javnosti premda su planovi morali biti na javnom uvidu u trajanju od mjesec dana. Kasniji transfer nadležnosti nad planiranjem na razinu općina omogućio je planerima priliku da više surađuju s lokalnim vlastima (Bojić, 2018). To, međutim, nije značilo i više interakcije s lokalnom javnošću; lokalne vlasti često je više zanimalo mišljenje investitora nego lokalnoga stanovništva (Piha, 1973).

\section{Okolišni aspek†}

Legislativa u ovoj etapi nije spominjala okolišne aspekte, no neki poticaji za zaštitu okoliša i stva-
N. Tandarić

C. Watkins

C. D. Ives

Urban planning in socialist Croatia

Urbano planiranje $\mathbf{u}$

Hrvatskoj tijekom socijalističkoga režima 
HRVATSKI

GEOGRAFSKI

GLASNIK

81/2, 5-41 (2019.) environment protection and provision of urban nature came from the UPIC which employed planners trained in Western Europe ${ }^{3}$. For instance, in 1949, the UPIC developed an urban plan for Zagreb (Fig. 2) that proposed new development on the extensive matrix of high-quality public green spaces (Antolić, 1949). The proposal was rejected, inter alia, as being too expensive to develop and maintain due to extensive greenspace (M. N., 1954).

\section{The period of the first republic urban planning legislation (1961-1973)}

Federal planning legislation from 1949 could not keep up with systemic changes introduced in the 1950s nor with rapid construction fostered by ranje zelenih površina u gradovima dolazili su od UIH-a koji je zapošljavao planere školovane i usavršavane po Europi. ${ }^{3}$ Primjerice, UIH je 1949. izradio urbanistički plan Zagreba (sl. 2) koji je predvidio novi razvoj i izgradnju na ekstenzivnoj matrici od visokokvalitetnih zelenih površina (Antolić, 1949). Prijedlog plana na kraju je odbačen jer je, između ostaloga, bio preskup za provedbu i održavanje zbog ekstenzivnih zelenih površina (M. N., 1954).

\section{Etapa prvoga republičkog zakona o urbanom planiranju (1961. - 1973.)}

Federalna planska legislativa iz 1949. postala je nedostatnom uslijed sistemskim promjena uvedenih u 1950-ima kao i rapidne izgradnje pod utjeca-

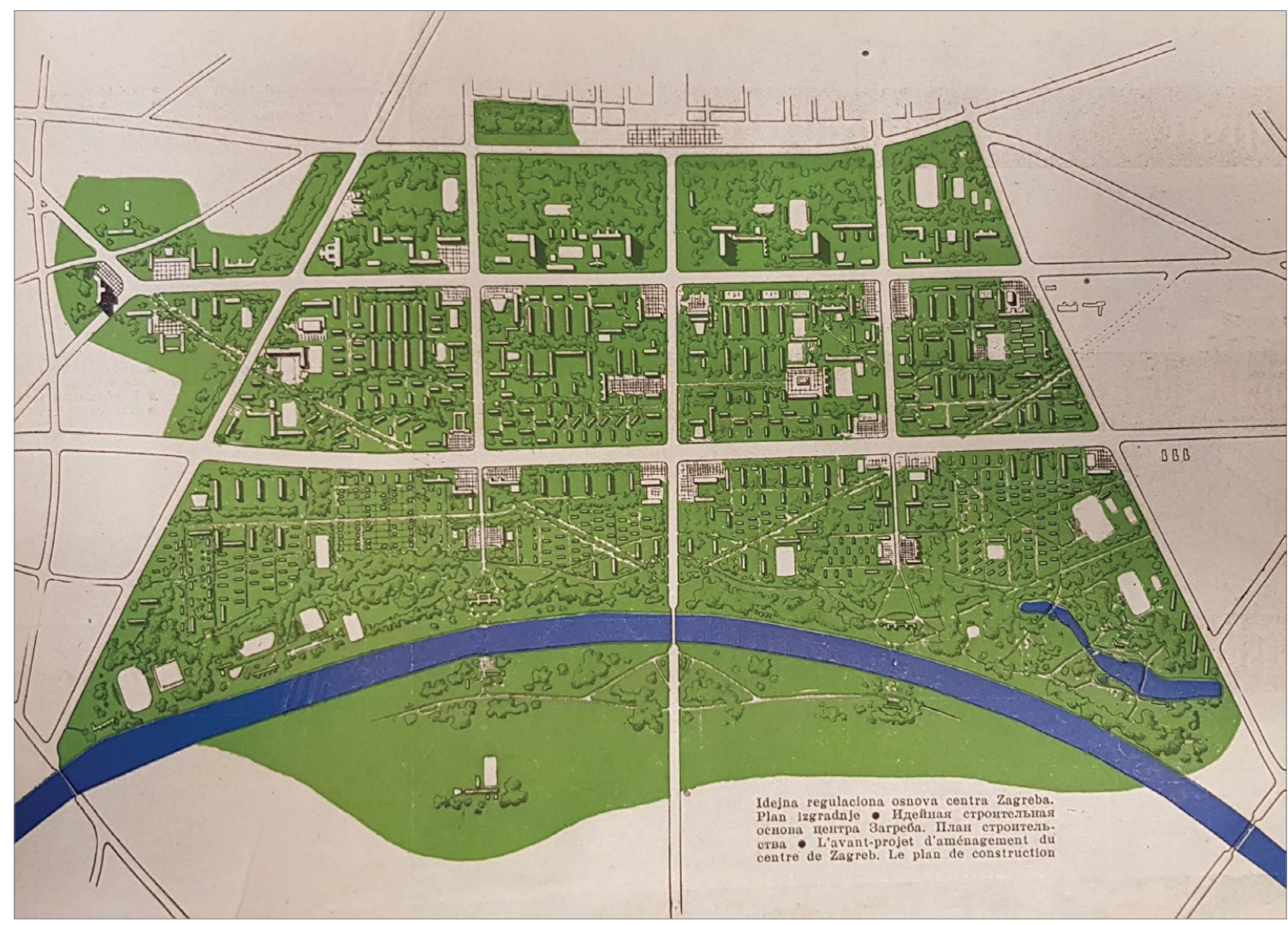

Fig. 2 The development plan of the new City Centre of Zagreb, part of the unadopted Regulation Plan of Zagreb of 1949 SI. 2. Razvojni plan novog centra Zagreba, dio neusvojenog Regulacionog plana i direktivne regulacione osnove Zagreba iz 1949 Source/Izvor: Antolić (1949)

\footnotetext{
3 It is noteworthy that between 1954 and 1958 the UPIC was led by Branko Petrović who had studied the legacy of the Garden City Movement in Sweden and England (Bojić, 2018).
}

3 Valja spomenuti da je između 1954.i 1958. direktor UIH-a bio Branko
Petrović koji se školovao u Švedskoj i Engleskoj izučavajući ostavštinu
pokreta vrtnih gradova (Bojić, 2018). 
industrialisation and urbanisation. However, the new law that passed in 1961 was immediately challenged by the constitutional changes of 1963 , which strengthened the self-management and communal systems and made steps towards making local communities, the lowest level administrative units, into self-managing organisations with specific responsibilities and authorities (Skupština SFRJ, 1963). The late 1960s and early 1970s were characterised with slowing economic growth and Yugoslavia's first political and economic adversities. Construction still thrived, but the economic situation threatened the completion of projects (Padgett, 1973). At the same time, urban settlements continued growing and, by 1971, two-fifths of Yugoslavians lived in cities (Žuljić, 1975). Nevertheless, urban plans had been adopted only for certain large cities by the mid1960s (Rendulić, 1966).

\section{Legislation}

The first post-war act on spatial planning was passed on 31 May 1961 (Sabor SRH, 1961). The act differentiated between urban and regional spatial plans, where the role of the urban plan was to direct the spatial development of a settlement and the regional plan directed the spatial development and organisation of regions. As a long-term document ( $\geq$ 20 years) the urban plan ${ }^{4}$ defined the land use, construction, reconstruction and sanitation conditions and it elaborated proposed solutions in economic and technical terms. The urban plan was conceived as a process starting with the urban plan programme that prescribed the guidelines for spatial development of a settlement and defined the objectives of the plan (Fig. 3). Following the programme, the GUP-the basic form of which having been adopted from the previous regulation-was then drafted serving as the legal planning document at the city level that defines the overall and zonal development of the city. Finally, the GUP was translated into one or more implementation or detailed urban plans (DUP), which minutely planned the implementation of GUP in a specific area of the city. In addition, small parts of the settlement, which were supposed to undergo substantial

4 For small settlements a decision could have been made, which would have then replaced the urban plan (Sabor SRH, 1961). jem industrijalizacije i urbanizacije. No i novi zakon usvojen 1961. ubrzo je doveden pred izazov kad su nove sistemske promjene 1963. dodatno osnažile komunalni i samoupravljački sustav te su poduzeti prvi koraci da se i mjesne zajednice, administrativne jedinice na najnižoj razini, pretvore u samoupravne organizacije sa specifičnim odgovornostima i nadležnostima (Skupština SFRJ, 1963). Kasne 1960-e i rane 1970-e obilježili su usporavanje gospodarskoga rasta te prve političke i gospodarske nedaće. Iako je gradnja nastavila bujati, gospodarska je situacija prijetila da bi započeti projekti mogli ostati nedovršeni (Padgett, 1973). U isto vrijeme urbana naselja nastavila su rasti te je do 1971. godine dvije trećine jugoslavenskih građana živjelo u gradovima (Žuljić, 1975). Pa ipak, do sredine šezdesetih samo je dio velikih gradova usvojio urbanističke planove (Rendulić, 1966).

\section{Zakonodavstvo}

Prvi poslijeratni zakon o prostornom planiranju usvojen je 31. svibnja 1961. Zakon o urbanističkom i regionalnom prostornom planiranju (Sabor SRH, 1961) razlikovao je urbanističke i regionalne planove, pri čemu je zadaća prvih bila usmjeravanje prostornoga razvoja naselja, dok je zadaća drugih bila usmjeravanje prostornoga razvoja i organizacije regija. Urbanistički su plano$\mathrm{vi}^{4}$ definirani kao dugoročni ( $\geq 20$ godina) planski dokumenti koji utvrđuju namjenu površina i uvjete gradnje, rekonstrukcije i asanacije te daju ekonomska i tehnička obrazloženja za predložena rješenja. Urbanistički je plan bio zamišljen kao proces koji počinje urbanističkim programom koji je propisivao smjernice za prostorni razvoj naselja i definirao zadatke plana (sl. 3). Na temelju programa izrađivao se GUP (dokument preuzet iz prethodne uredbe) koji je služio kao pravni planski dokument na razini grada koji je određivao njegov sveukupni i zonalni razvoj. Konačno, GUP se "prevodio" u jedan ili više provedbenih ili detaljnih urbanističkih planova (DUP) koji su precizno planirali implementaciju GUP-a u određenom dijelu grada. Osim tih dokumenata, za manje dije-

\footnotetext{
4 Za manja naselja mogla se donijeti odluka koja zamjenjuje urbanistički plan ili dio urbanističkoga plana (Sabor SRH, 1961).
}

Urban planning in socialist Croatia

Urbano planiranje $u$

Hrvatskoj tijekom socijalističkoga režima 
HRVATSKI

GEOGRAFSKI

GLASNIK

$81 / 2,5-41(2019$.

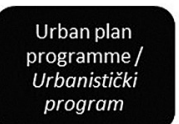

- guidelines for spatial development of a settlement/

smjernice za prostorni razvoj naselja

- objectives of the plan / zadaci plana

- land use plan / plan namjene površina

- basic conditions for construction, reconstruction and sanitation in the settlement /

osnovni uvjeti gradnje, rekonstrukcije i asanacije naselja

urbanističkiplan - economic and technical elaboration of proposed solutions / ekonomsko i tehničko

obrazloženje predloženog rješenja

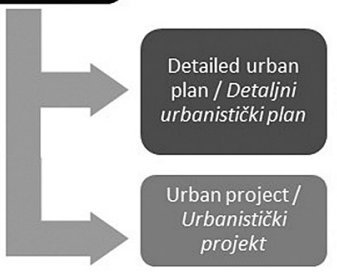

- geodetic and other land data / geodetskii drugi podaci o zem/jištu - detailed land use plan / detaljni plan namjene površina

- building conditions / urbanistički uvjeti

Fig. 3 Scheme of the urban planning document sequence according to the 1961 Urban and Regional Spatial Planning Act

SI. 3. Shematski prikaz slijeda dokumenata urbanog planiranja prema Zakony o urbanom i regionalnom prostornom planiranju iz 1961 construction or reconstruction, could also be spatially arranged by drafting an urban project instead of a DUP.

An urban plan, i.e. all of its elements, would be adopted by communal assemblies, after being drafted by a working organisation registered for urban planning activities. Plans had to be revisited at least every five years (Sabor SRH, 1961). However, although the republic urban planning acts in Yugoslavia were carefully drafted, their implementation was often hindered in practice. Branislav Piha (1973) speculated that the reasons for this were the lack of an urban planning culture, lack of awareness of the importance of organised and directed construction, conflicts between interested parties, etc.

\section{Relation to societal planning}

For the first time, urban planners had to analyse natural, social, and economic conditions in the planned territory to facilitate planning. The analysis results were part of the urban planning programme (Sabor SRH, 1961) and were supposed to support societal plans and economic development. Nevertheless, economic development slowed down in the 1960s and there was an economic crisis. As part of the resulting reform, the rationalisation of infrastructure investments, and locational decisions were integrated into a renewed system of societal planning (Burton et al., 1966) changing the position of urban planning once again (Piha, 1973). Societal planning formally became an umbrella for love naselja za koje se predviđala značajna gradnja ili rekonstrukcija mogli su se umjesto DUP-ova donijeti urbani projekti.

Urbanistički plan odnosno sve njegove sastavnice, koje je izradila radna organizacija kojoj je to predmet poslovanja, usvajala je općinska skupština. Planovi su trebali biti razmatrani najmanje svakih pet godina (Sabor SRH, 1961). Iako su republički zakoni bili profesionalno dobri, njihova je provedba često zaostajala u praksi. Branislav Piha (1973) nagađa da su razlozi tomu nedostatak kulture urbanoga planiranja, manjak svijesti o potrebi organizirane i usmjerene gradnje, konflikti između različitih dionika i dr.

\section{Odnos prema društvenom planiranju}

Po prvi su put urbani planeri pri izradi planova morali analizirati prirodne, socijalne i ekonomske uvjete na planiranom području, a rezultati te analize bili su sastavni dio urbanističkoga programa i trebali su poduprijeti društvene planove i gospodarski razvoj (Sabor SRH, 1961). Ipak, gospodarski je razvoj šezdesetih godina počeo usporavati dovodeći do gospodarske krize. Kao odgovor na to provedena je reforma kojom je, između ostaloga, u unaprijeđeni sustav društvenoga planiranja uvedena racionalizacija infrastrukturnih ulaganja i lokacijskih odluka (Burton i dr., 1966) čime se položaj urbanoga planiranja opet promijenio (Piha, 1973). Društveno planiranje i formalno je postalo krovni koncept za 
all planning, and along with that the comprehensive planning system involved seven types of plans (federation, republic, regional, communal, plans of labour organisations and their associations) out of which the seventh type were physical plans (Rendulić, 1966). Spatial planning was definitively subordinated to social planning. The anticipated role of physical plans was, using long-term economic and demographic forecasts, to plan infrastructure, arrange optimal locations of basic economic capacities and social services and settlement networks, and inform the direction of urban planning and the urbanisation processes (Frković, 1966). In a way, the intended role of societal planning was the systematic networking of physical plans with federal financial plans and the economic plans of enterprises (Burton et al., 1966).

\section{Political-institutional responsibility}

The central government body responsible for spatial planning at the time was the Republic Bureau for Urban Planning, Housing, and Communal Affairs. Its primary role was to provide technical guidelines for plan drafting, to control compliance between different plans and subsequently to give consent to urban plans. On a local level, every commune had an administrative body responsible for urban planning which organised planning and plan implementation. At the beginning of the plan making process, that body was supposed to found a professional planning commission which would draft the urban planning programme and evaluated the subsequent planning phases (Sabor SRH, 1961). Furthermore, the trend of founding spatial planning bureaus in this period continued, and many urban communes gained their own bureaus (Piha, 1973).

\section{Urban planners and policy}

Following the tradition set in the pre-war period, urban planning in post-war Yugoslavia was still a technical rather than social discipline, dominated by architects, which was a cause of emerging criticism (Fisher, 1965; Lay, 1975). Over 65\% of the staff of urban planning offices in Yugoslavia were sve vidove planiranja te je u novom, objedinjenom sustavu planiranja definirano sedam vrsta planova (federalni, republički, regionalni, općinski, planovi radnih organizacija i planovi njihovih asocijacija) od kojih su sedma vrsta bili prostorni planovi (Rendulić, 1966). Prostorno je planiranje definitivno podređeno društvenom planiranju. Predviđena uloga prostornih planova bila je planiranje infrastrukture, optimalne distribucije osnovnih gospodarskih kapaciteta, objekata društvenih službi i mreže naselja te usmjeravanje urbanizacijskih procesa, sve to kroz dugoročne ekonomske i demografske projekcije (Frković, 1966). Na neki je način uloga društvenoga planiranja postala sustavno umrežavanje prostornih planova s federalnim financijskim planovima i gospodarskim planovima poduzeća (Burton i dr., 1966).

\section{Političko-institucionalna nadležnost}

Tijelo („organ”) središnje vlasti nadležno za prostorno planiranje bio je Republički zavod za urbanizam, stambene i komunalne poslove. Njegova je primarna uloga bila pružati tehničke upute za izradu planova, nadzirati usklađenost između različitih planova i konačno davati primjedbe na prijedloge planova. $\mathrm{Na}$ lokalnoj razini svaka je općina imala tijelo nadležno za urbano planiranje koje je organiziralo planski proces i provedbu plana. Na početku procesa izrade plana to je tijelo trebalo osnovati stručnu plansku komisiju koja bi pripremila urbanistički program i ocjenjivala naredne faze planskoga procesa (Sabor SRH, 1961). Trend osnivanja prostornoplanskih zavoda nastavljen je te su mnoge gradske općine dobile svoje zavode u ovoj etapi (Piha, 1973).

\section{Urbani planeri i planerska praksa}

Slijedeći tradiciju uspostavljenu u predratnom razdoblju, urbano planiranje u drugoj Jugoslaviji i dalje je bilo više tehnička nego društvena disciplina, a koju su i dalje predvodili arhitekti što je postalo uzrokom sve češće kritike (Fisher, 1965; Lay, 1975). Gotovo dvije trećine osoblja urbanoplanskih
N. Tandarić

C. Watkins

C. D. Ives

Urban planning in socialist Croatia

Urbano planiranje $u$

Hrvatskoj tijekom socijalističkoga režima 
architects (Fisher, 1965). This was true also for the UPIC, which, in 1962, consisted of mainly urban architects, horticultural architects, architectural technicians, and drafters with a smaller number of urban experts from different disciplines: economists; geographers; sociologists; professionals in the domains of housing and infrastructure; and cartographers (Premužić, 1962). The societal role of urban plans was hampered as planners received little or no training in psychology, sociology, and philosophy (Padgett, 1973). Consequently, plans were often technically faultless but failed to deliver a humanistic city that would advance the social environment, interactions, and individual contentment. Starting in the 1960s, professionals from other disciplines (economics, geography, sociology) were asked more frequently to participate in urban planning (Lay, 1975). Nevertheless, architects remained dominant in planning as urban planning was only taught in faculties of architecture (Piha, 1973).

Urban planning institutes remained influential professional bodies, which were employed by both domestic and foreign contractors to develop urban and regional plans. A notable example is the urban plan of Conakry, Guinea which was drafted by the UPIC in the early 1960s (Petrinović, 1962; Premužić, 1962). Most of the international activity was accomplished in non-aligned and developing countries. In domestic terms, one of the most important endeavours was the joint project between the United Nations and the (Yugoslav) federal government aimed at developing physical plans for the Adriatic Region between 1963 and 1972, in order to plan intensive urban development on the coast. As a result of the project, several cities were developed according to the urban plans and designs drafted by the UPIC, demonstrating an alternative to the emerging intensive, uncontrolled growth of holiday accommodation on the Adriatic coast (Salaj, 1988).

\section{Plan execution}

Once an urban plan was adopted, the planning commission was responsible for scheduling and monitoring its execution (Sabor SRH, 1961). The Commission collaborated with the communal fund for housing construction which defined housing ureda u Jugoslaviji činili su arhitekti (Fisher, 1965). To je vrijedilo i za UIH koji su 1962. činili primarno urbani i hortikulturni arhitekti, arhitektonski tehničari i crtači s tek malim brojem stručnjaka iz drugih disciplina: ekonomista, geografa, sociologa, stručnjaka u oblastima stanovanja i infrastrukture te kartografa (Premužić, 1962). Društvena uloga urbanističkih planova bila je sputana i time što su planeri školovani primarno za tehničke vještine, dok je obuka iz psihologije, sociologije i filozofije bila zanemarena (Padgett, 1973). Kao rezultat toga planovi su često bili tehnički bez greške, ali nisu mogli stvoriti humane gradove u kojima bi društveno okruženje, interakcije i osobno zadovoljstvo bili unaprijeđeni. Od 1960-ih stručnjaci iz drugih disciplina (ekonomije, geografije i sociologije) počeli su češće sudjelovati u urbanom planiranju (Lay, 1975). No arhitekti su nastavili predvoditi planiranje s obzirom na to da se kvalifikacija urbanista mogla steći samo na arhitektonskim fakultetima (Piha, 1973).

Urbanistički instituti ostali su utjecajne strukovne organizacije koje su za razvoj urbanih i regionalnih planova ugovarali i domaći i strani klijenti. Valja spomenuti primjer urbanističkoga plana Conakryja u Gvineji koji je UIH izradio u ranim šezdesetima (Petrinović, 1962; Premužić, 1962). Većina međunarodne aktivnosti ostvarena je u nesvrstanim i zemljama u razvoju. U domaćim okvirima jedno od najvažnijih nastojanja bio je zajednički projekt između Ujedinjenih naroda i federalne vlade proveden između 1963. i 1972. godine s ciljem razvoja prostornih planova za Jadransku regiju da bi se usmjerio već intenzivan urbani razvoj na obali. Kao rezultat toga izgrađeno je nekoliko gradova prema urbanističkim planovima i projektima UIH-a koji su trebali demonstrirati alternativu rastućem intenzivnom i nekontroliranom razvoju smještaja za odmor na jadranskoj obali (Salaj, 1988).

\section{Provedba planova}

Jednom kad je urbanistički plan bio usvojen, planska komisija bila je odgovorna za planiranje i praćenje provedbe (Sabor SRH, 1961). Komisija bi surađivala s komunalnim fondom za stambenu izgradnju koji je definirao lokalnu stambenu politiku 
policy and selected areas for residential expansion. In ideal cases, the office responsible for communal construction then prepared the land in selected areas for construction and equipped it with necessary utilities. Such offices were frequently founded in the 1960s as earlier experience showed that the lack of coordination in projection and construction of utilities often created a bottleneck in urban development (Fisher, 1965). In practice, however, this scenario was inverted: informal construction continued to be tolerated and even increased in coastal Croatia due to the growth of tourism. Such individual interests hindered the implementation of plans. The few examples of legal prosecution were long-lasting cases, which also had the effect of preventing the achievement of short-term planning goals (Dakić et al., 1972).

\section{Public participation}

In this period spatial planning outgrew the professional frame and became a social activity; spatial plans became objects of public interest and discussion (Piha, 1973). The act prescribed that communes had to ensure the participation of all interested workers' and other organisations in plan development, but in practice, plans were formulated in planning offices and did not involve public participation until the final stage (Pogačnik, 1987). Once the urban plan was finished, the commune displayed the proposal to the public and gave a deadline for comments (Sabor SRH, 1961). Remarks were expected from relevant organisations like local communities, voters' meetings and apartment house councils rather than from individual citizens (Fisher, 1965). In theory, planning reflected the intention to respect the plurality of spatial interests, and consensus between different interest groups was supposed to shape the final plan ( $\mathrm{Da}-$ bović et al., 2017).

In practice, public review rarely resulted in substantial changes and could never reject the proposal completely (Pogačnik, 1987). Despite the constitutional declaration of a 'classless society', in reality, certain interest groups and individuals such as builders and developers were usually powerful enough to influence plans in the drafting phase. i odabirao lokacije za stambeno širenje. U idealnim bi slučajevima onda općinski odjel nadležan za komunalnu gradnju pripremio zemljište na odabranim lokacijama za gradnju i opremio ga komunalnom infrastrukturom. Takvi su odjeli često osnivani u šezdesetima s obzirom na to da su ranija iskustva pokazala da je manjak koordinacije između projektiranja i gradnje komunalne infrastrukture često stvarao tzv. usko grlo u urbanom razvoju (Fisher, 1965). U praksi je, međutim, taj scenarij nerijetko bio obrnut: „divlja” gradnja se i dalje tolerirala te je u obalnim krajevima i pojačana zbog razvoja turizma. Takvi pojedinačni interesi otežavali su provedbu planova. Onih nekoliko primjera kad su se takvi slučajevi i pravno sankcionirali pokazuju zapravo dugotrajne postupke koji su svejedno onemogućavali ostvarenje kratkoročnih planskih ciljeva (Dakić i dr., 1972).

\section{Sudjelovanje javnosti}

U ovoj je etapi prostorno planiranje nadraslo stručni okvir i postalo društvena aktivnost; prostorni planovi postali su objektom javnoga interesa i odlučivanja (Piha, 1973). Zakon je propisao da općine moraju osigurati sudjelovanje svih zainteresiranih radnih $\mathrm{i}$ drugih organizacija u razvoju planova, no u praksi su planovi bili formulirani u planskim uredima i nisu uključivali sudjelovanje javnosti sve do posljednje faze (Pogačnik, 1987). Jednom kad je urbanistički plan bio završen, općina bi ga stavila na javni uvid i odredila rok za podnošenje primjedbi i komentara (Sabor SRH, 1961). Primjedbe su se očekivale od relevantnih organizacija i tijela poput mjesnih zajednica, glasačkih zborova i vijeća stanara, a najmanje od pojedinaca (Fisher, 1965). U teoriji je planiranje trebalo odražavati namjeru da se poštuje pluralnost prostornih interesa te je konsenzus između različitih interesnih skupina trebao oblikovati konačni plan (Dabović i dr., 2017).

U praksi je javni uvid rijetko rezultirao značajnim promjenama i praktički nikad nije mogao dovesti do potpuna odbijanja prijedloga plana (Pogačnik, 1987). Usprkos ustavnoj deklaraciji o besklasnom društvu u stvarnosti su pojedine interesne skupine i pojedinci poput građevinara i investitora bili dovoljno utjecajni da već u fazi izrade plana u
N. Tandarić

C. Watkins

C. D. Ives

Urban planning in socialist Croatia

Urbano planiranje u

Hrvatskoj tijekom socijalističkoga režima 
Their impact was often most evident in DUPs which arranged concrete elements in space (Dakić et al., 1972). Other residents and groups could participate effectively only in the public display phase. If remarks targeted the concept or underlying principles of the proposed plan, the proposal was usually not altered. However, if remarks addressed issues that were not related to the fundamental concept of the plan, then they were often received more favourably, especially if the proposing group could secure necessary resources to carry out the suggested change(s) (Fisher, 1965). In the end, the decision on adoption and substantial change of plans most often depended on the support given by political bodies and developers who financed the projects (Pogačnik, 1987).

\section{Environmental concerns}

As a result of the 1957 Expropriation Act, many surfaces between buildings were designated as social property so they would not hinder any potential future land developments, and were left as grassy meadows. These areas, however, were often too small and inappropriate for development and burdened the communal budget for maintenance, leading to a lack of management (Marinović-Uzelac, 1993).

The act did not address environmental concerns, although it loosely stated that urban plan had to define the construction, reconstruction, and sanitation conditions for areas containing protected natural objects. In such legal settings, the elimination of adverse effects of fast urban growth on the environment was questionable (Petrović, 1971), depending on planners' individual stances towards such issues. However, even though not legally binding, some environmental issues were usually considered to some degree since residents had the right to appeal if the plan would result in increased local traffic noise or air pollution (Pogačnik, 1987).

\section{The period of "2000" plans (1973-1980)}

The reforms of the mid-1960s did not improve the situation. Yugoslavia was faced with increasing unemployment and poverty, economic emigration, uredima utječu na njegov sadržaj. Njihov je utjecaj često bio najočitiji u DUP-ovima koji su uređivali konkretne elemente u prostoru (Dakić i dr., 1972). Ostali stanovnici i skupine mogli su efektivno sudjelovati samo u fazi javnoga uvida. Ako su se njihove primjedbe odnosile na koncept ili temeljna načela prijedloga plana, prijedlog obično ne bi bio mijenjan, ali ako su se odnosile na pitanja koja nisu bila povezana s temeljnim konceptom plana, onda bi ona mnogo češće bila usvojena, posebice ako bi predlagajuća skupina mogla osigurati i potrebna sredstva za predložene intervencije (Fisher, 1965). $\mathrm{Na}$ kraju krajeva odluka o usvajanju i značajnim izmjena plana najčešće je ovisila o podršci političkih tijela $\mathrm{i}$ investitora koji su financirali projekte ( $\mathrm{Po}^{-}$ gačnik, 1987).

\section{Okolišni aspekt}

Još od zakona o eksproprijaciji iz 1957. mnoge su površine među zgradama određene kao društveno vlasništvo da ne bi otežavale potencijalne buduće razvojne projekte te su ozelenjavane. Te su površine, međutim, često bile premalene i neprikladne za bilo kakvu svrhu te je njihovo održavanje samo opterećivalo općinski budžet zbog čega često nisu ni bile održavane (Marinović-Uzelac, 1993).

Zakon nije propisivao postupke brige o okolišu premda je naveo da urbanistički planovi moraju definirati uvjete gradnje, rekonstrukcije i asanacije za područja koja sadrže zaštićene objekte prirode. U takvim je pravnim okvirima eliminacija negativnih učinaka brzoga urbanog rasta na okoliš bila u najmanju ruku upitna (Petrović, 1971), oviseći o pojedinačnim stajalištima planera o takvim pitanjima. Međutim, iako pravno neobvezujući, neki vidovi sagledavanja okoliša obično bi ipak bili razmatrani jer su stanovnici imali pravo prigovora ako bi plan rezultirao primjerice lokalnim povećanjem prometne buke ili onečišćenja zraka (Pogačnik, 1987).

\section{Ełapa planova „2000." (1973. - 1980.)}

Reforme od sredine 1960-ih nisu bitno popravile stanje i Jugoslavija se počela suočavati s rastućom nezaposlenošću i siromaštvom, ekonomskom 
as well as national uprisings (Benson, 2004). In order to ease the situation, the communist party issued a new constitution which increased the republics' autonomy and strengthened the self-management system by reorganising it and further extending the powers and responsibilities of communes. All institutions and organisations providing public services such as health, education, transport, etc. were transformed into self-managed interest communities (SMICs), which operated across different levels-from local communities through communes to republics. Workers organisations and enterprises were transformed into organisations of associated labour (OALs) (Grbić, 1975; Simmie and Hale, 1978). Urban planning began to change as well and to depart from post-war internationalism (Premerl, 1986). New legislation was developed along with the constitutional changes and included the principles of the previous societal planning system reform. Consequently, urban plans were developed systematically to cover a long-term period, serving as a basis for societal planning.

\section{Legislation}

The term "urban planning" was removed from the title of the new act, issued in 1973. And replaced with the term "spatial planning". The act more clearly elaborated the system of physical planning documents than the previous acts and combined physical planning with construction. The novelty was the system of physical plans divided into development (long-term: 20-30 years) and implementation (short-term) plans. Development plans covered different spatial scales-from republic, through regional and communal, to the urban settlement level. Urban plans covered the lowest spatial level (excluding plans for areas of special purpose) and were adopted for cities and larger settlements. That was also the only level for which implementation plans were projected (Sabor SRH, 1973).

The sequence of urban plan documents was changed. The category of urban planning programme was replaced by a category called spatial development conception, and this was not mandatory. However, the act suggests that cities of re- emigracijom te nacionalističkim pokretima (Benson, 2004). Kako bi smirila situaciju, Komunistička je partija 1974. donijela novi ustav koji je povećao autonomiju republika $i$ još više osnažio sustav samoupravljanja kroz njegovu reorganizaciju i daljnje povećanje ovlasti i odgovornosti općina. Sve institucije i organizacije koje su pružale javne usluge iz sektora poput zdravstva, obrazovanja, prometa pretvorene su u samoupravne interesne zajednice (SIZ) koje su djelovale na različitim razinama - od mjesnih zajednica preko općina do republika. Radne organizacije i poduzeća su pak transformirana u organizacije udruženoga rada (OUR) (Grbić, 1975; Simmie i Hale, 1978). Urbano planiranje također se počelo mijenjati i odmicati od poslijeratnoga internacionalizma (Premerl, 1986). Razvijena je nova legislativa usporedno s ustavnim promjena te je uključivala načela uvedena prethodnom reformom sustava društvenoga planiranja. Slijedom toga su i urbanistički planovi izrađivani tako da pokriju dugoročno razdoblje i posluže kao osnova društvenom planiranju.

\section{Zakonodavstvo}

Pojam „urbano planiranje” uklonjen je iz naziva novoga zakona koji je usvojen 1973., odnosno zamijenjen je pojmom „prostorno planiranje”. Zakon o prostornom planiranju i korištenju građevinskoga zemljišta iscrpnije je i preciznije elaborirao sustav dokumenata prostornoga planiranja u odnosu na prethodni zakon te je legislativno kombinirao prostorno planiranje s gradnjom. Novost je bila i sustav prostornih planova koji je diferencirao razvojne (dugoročne: 20-30 godina) i provedbene (kratkoročne) planove. Razvojni planovi donosili su se na različitim razinama - od republičke preko regionalne i općinske do razine urbanoga naselja. Urbanistički planovi pokrivali su, dakle, najnižu prostornu razinu (kad se izuzmu planovi područja posebne namjene) te su se usvajali za gradove i veća naselja. To je bila i jedina razina na kojoj su se donosili provedbeni planovi (Sabor SRH, 1973).

Slijed dokumenata urbanoga planiranja također je promijenjen. Urbanistički program zamijenjen je koncepcijom prostornoga razvoja koja više nije bila obvezatna kategorija. Ipak, zakon je preporuči-
N. Tandarić

C. Watkins

C. D. Ives

Urban planning in socialist Croatia

Urbano planiranje u

Hrvatskoj tijekom socijalističkoga režima 
HRVATSKI

GEOGRAFSKI

GLASNIK

81/2, 5-41 (2019.)

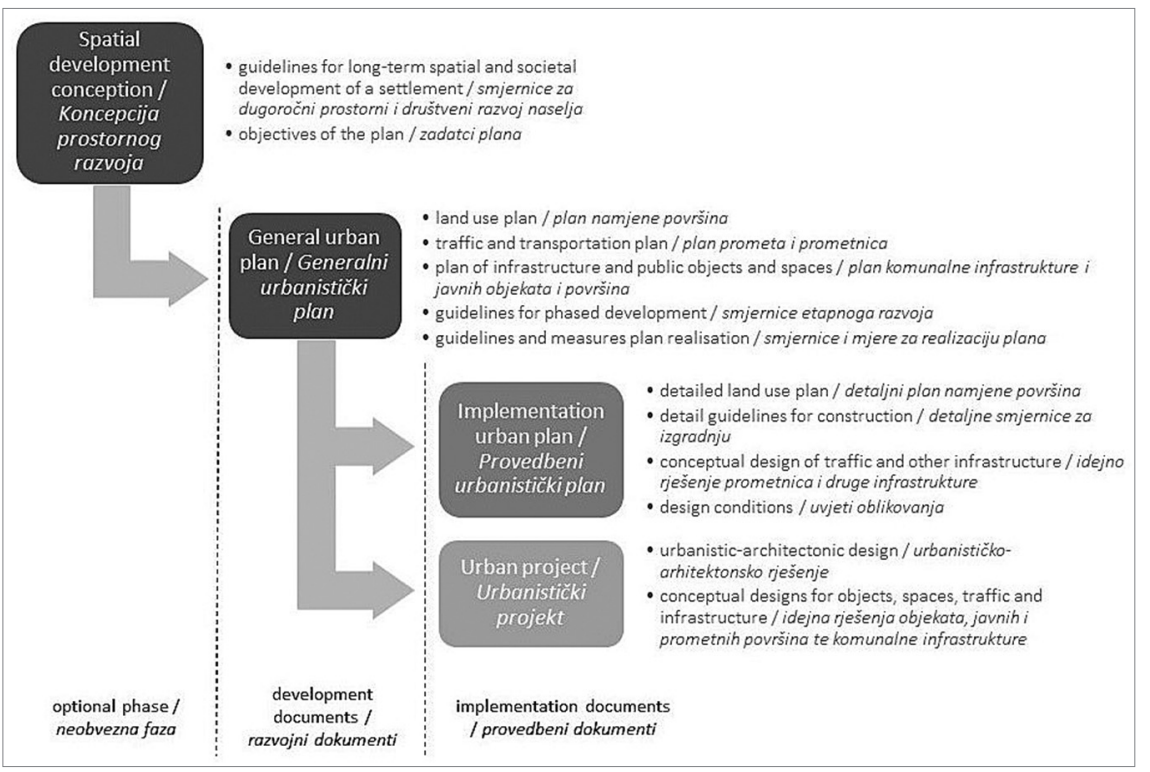

Fig. 4 Scheme of the urban planning document sequence according to the 1973 Physical Planning and Construction Land Use Act

SI. 4. Shematski prikaz slijeda dokumenata urbanog planiranja prema Zakonu o prostornom uređenju i korištenju građevinskog zemlijista (1973) gional importance, such as Zagreb or Split, Zadar, Varaždin, etc., should draft "conceptions" before making GUP5. Similarly the DUP was replaced by implementation urban plan (IUP) which could also be developed in two phases, where the first part was the programme for drafting the DUP. The content of the urban plan, i.e. its components, was defined more thoroughly than in previous laws. Another novelty was that an urban plan could also cover the undeveloped area surrounding a city, which was anticipated to be developed over the planned period (Sabor SRH, 1973) (Fig. $4)$.

\section{Relation to societal planning}

Following the societal planning reform from the previous decade, the new act anchored urban planning in the system of societal planning. The act defined that the OALs drafting an urban plan had to collaborate with bodies and organisations in charge of societal planning. Moreover, urban plans had to be revisited every five years to ensure compliance with societal and other plans (Sabor SRH, 1973). The system of societal planning was further arranged by the 1976 federal Act on Foun-

\footnotetext{
5 In the act, GUP was mentioned only in the article that suggests drafting the conception which precedes it. In all other articles the development plan of a city was called an urban plan.
}

vao da gradovi regionalne važnosti, poput Zagreba ili Splita, do razine Zadra, Varaždina i sl., izrađuju koncepciju prije izrade GUP-a. ${ }^{5}$ Slično tomu DUP je zamijenjen provedbenim urbanističkim planom (PUP) te je također mogao biti razvijan u dvije faze gdje je prvu činio detaljni program za izradu PUP-a. Sadržaj urbanističkoga plana, odnosno njegovih sastavnica, definiran je iscrpnije nego u prethodnim zakonima. Druga novost bila je da su urbanistički planovi mogli pokrivati i neizgrađene dijelove u okolici gradova koji su bili predviđeni za razvoj tijekom planskoga razdoblja (Sabor SRH, 1973) (sl. 4).

\section{Odnos prema društvenom planiranju}

Slijedeći reformu iz prethodnog desetljeća, novi je zakon učvrstio položaj urbanoga planiranja u sustavu društvenoga planiranja. Zakon je definirao da OUR-i koji izrađuju planove moraju surađivati s tijelima i ustanovama odgovornima za društveno planiranje. Štoviše, urbanistički planovi morali su biti revidirani svakih pet godina kako bi se osigurala njihova usklađenost $\mathrm{s}$ društvenim i drugim planovima (Sabor SRH, 1973). Sustav društvenoga planiranja dodatno je uređen federalnim Zakonom

\footnotetext{
5 GUP se u Zakonu spominje jedino u članku koji predviđa izradu koncepcije koja mu prethodi. U svim drugim člancima razvojni plan grada naziva se urbanističkim planom.
} 
dations of the Planning System and the Societal Plan of Yugoslavia, and the 1978 Act on Societal Planning in SR Croatia. In light of these changes, many urban planning bureaus were transformed into societal planning bureaus (Dabović et al., 2017).

In a way, various societal and urban plans were considered as plans and goals for building a socialist society (Franković, 1985). In line with that, in the 1970s, many cities brought out so-called "2000" urban plans which were supposed to conform with the legal premise of long-term plans (Pogačnik, 1987). Furthermore, regional and republic plans had to be adopted, which, among other aspects, considered the possible variants of the overall urban system. The Spatial plan of the SR Croatia from 1974 thus considered the following three variants: 1 ) concentration of population and central functions in the centres of the Zagreb, Split, Rijeka and Osijek macro-regions; 2) a disperse system of central settlements and population; and 3) a mid-variant-the latter was considered optimal (Radeljak, 2012).

\section{Political-institutional responsibility}

In institutional terms, the new legislation did not bring significant change. Communes remained the initial level at which urban planning was conducted, as urban plan making was considered part of a communes' self-management (Simmie, 1989). Before adoption, communes had to submit their urban plans to the republic body responsible for urban planning which evaluated the plan's compliance with other spatial and societal plans, technical urban planning standards, and planning legislation (Sabor SRH, 1973).

\section{Urban planners and policy}

For the first time, the legislation prescribed which organisations could draft plans in terms of the staff they must possess. These were primarily OALs registered for planning that employed at least two architects and six professionals from other relevant disciplines (economics, traffic engineering, infrastructure, etc.). Except for OALs, o osnovama sustava planiranja i društvenog plana Jugoslavije iz 1976. te Zakonom o društvenom planiranju u SR Hrvatskoj iz 1978. godine. U svjetlu tih promjena pojedini su urbanistički zavodi transformirani u zavode za društveno planiranje (Dabović i dr., 2017).

Može se reći da su različiti društveni i urbani planovi smatrani planovima i ciljevima za izgradnju socijalističkoga društva (Franković, 1985). U skladu s tim su se u 1970-ima donosili tzv. planovi „2000." kojima se trebala ostvariti zakonska premisa o dugoročnim planskim dokumentima (Pogačnik, 1987). Nadalje, regionalni i republički planovi koji su se također morali usvojiti trebali su između ostaloga razmotriti i moguće varijante cjelokupnoga urbanog sustava. Prostorni plan SR Hrvatske iz 1974. tako razmatra sljedeće varijante: 1 ) koncentraciju stanovništva i centralnih funkcija u središtima makroregija Zagreba, Splita, Rijeke i Osijeka, 2) disperzirani sustav središnjih naselja i stanovništva te 3) međuvarijantu; posljednja je smatrana optimalnom (Radeljak, 2012).

\section{Političko-institucionalna odgovornost}

$\mathrm{U}$ institucionalnim okvirima nova legislativa nije donijela važnije promjene. Općine su ostale osnovna razina na kojoj se provodilo urbano planiranje s obzirom na to da su urbanistički planovi smatrani dijelom općinskoga samoupravljanja (Simmie, 1989). Prije usvajanja općine su morale poslati prijedlog urbanističkoga plana republičkom tijelu nadležnom za urbano planiranje koje je ocjenjivalo usklađenost prijedloga s drugih prostornim i društvenim planovima, tehničkim standardima urbanoga planiranja i planskim zakonodavstvom (Sabor SRH, 1973).

\section{Urbani planeri i planerska praksa}

Po prvi je put legislativa propisala koje organizacije mogu izrađivati planove u smislu kadra koji moraju zapošljavati. To su bili ponajprije OUR-i registrirani za planiranje koji su zapošljavali najmanje dva arhitekta i šest stručnjaka iz drugih relevantnih disciplina (ekonomije, prometnoga inženjerstva, infrastrukture, itd.). Osim OUR-a ur-
N. Tandarić

C. Watkins

C. D. Ives

Urban planning in socialist Croatia

Urbano planiranje u

Hrvatskoj tijekom socijalističkoga režima 
urban plans could also be drafted by academic institutions (Sabor SRH, 1973). Work in the interdisciplinary team was not, however, always successful due to the lack of planning education outside of architecture faculties as well as different viewpoints originating from different disciplines (Pogačnik, 1987).

Nevertheless, many spatial planning organisations (UPIC, Zagreb Urban Planning Bureau, Dalmatia Urban Planning Bureau, Zadar Urban Planning Bureau, Đakovo Urban Planning Bureau, Rijeka Urban Planning Bureau, Osijek Urban Planning Bureau, URBIS Pula) already employed assorted professionals and offered various services. Further, OALs could act as consultants to both public and private organisations in need of urban planning services (Simmie, 1989). In the light of legislation changes, the UPIC organised professional seminars in Zadar and Zagreb in 1973 and 1974 on the development and drafting of plans under the new socio-political conditions. The UPIC retained the role of the innovator in the methodology of planning documents as well as planning-related studies (Salaj, 1988).

\section{Plan execution}

Long-term urban plans were realised through short-term IUPs and, in special cases, by urban projects. These documents defined technical planning conditions for development, construction, reconstruction and sanitation of the planned area. In contrast to the IUP which concerned an area (or its part) that was covered by the GUP, the urban projects could relate only to small parts of the city, which were supposed to undergo substantial construction or reconstruction (Sabor SRH, 1973). Regarding informal construction, it continued to be tolerated and, consequently, hindered normal execution of urban plans.

\section{Public participation}

The 1973 Act defined spatial planning as a right and obligation of socio-political communities, primarily communes. Subsequently, the communal assembly was obliged to ensure the participation of banističke planove mogle su izrađivati i akademske ustanove (Sabor SRH, 1973). Rad u interdisciplinarnim timovima nije, međutim, uvijek bio uspješan s obzirom na manjak planerskoga obrazovanja $\mathrm{u}$ visokoškolskim ustanovama izuzev arhitektonskih fakulteta kao i drukčijih stanovišta koja su trebala potjecati iz različitih disciplina (Pogačnik, 1987).

Tadašnje ili doskora osnovane prostornoplanerske organizacije u Hrvatskoj (UIH, Urbanistički zavod grada Zagreba, Urbanistički zavod Dalmacije, Urbanistički zavod Zadar, Urbanistički zavod Đakovo, Urbanistički zavod ZO Rijeka, Urbanistički zavod ZO Osijek, URBIS Pula) već su zapošljavale različite struke i nudile raznovrsne usluge. Nadalje, OUR-i su mogli djelovati i kao konzultanti za javne i za privatne naručitelje kojima su bile potrebne usluge urbanoga planiranja (Simmie, 1989). U svjetlu legislativnih promjena UIH je upriličio stručne seminare u Zadru i Zagrebu 1973. i 1974. godine o razvoju i izradi planova u novim sociopolitičkim uvjetima. I u ovoj je etapi UIH zadržao ulogu inovatora u metodologiji izrade planskih dokumenata i studija vezanih uz planiranje (Salaj, 1988).

\section{Provedba planova}

Dugoročni urbanistički planovi ostvarivani su kroz kratkoročne PUP-ove i, u posebnim slučajevima, urbanističke projekte. Ti su dokumenti određivali urbanističko-tehničke i druge uvjete razvoja, izgradnje, rekonstrukcije i sanacije planiranoga područja. Za razliku od PUP-a, urbanistički projekti mogli su se donositi samo za manje dijelove grada za koje se predviđala značajna gradnja ili rekonstrukcija (Sabor SRH, 1973). Što se tiče neformalne izgradnje, ona se nastavila tolerirati, što je otežavalo provedbu planova.

\section{Sudjelovanje javnosti}

Zakon iz 1973. definirao je prostorno planiranje kao pravo i obvezu društvenopolitičkih zajednica, prvenstveno općina. Sukladno tomu općinska skupština morala je osigurati sudjelovanje mjesnih 
local communities, OALs, SMICs, and residents in the decision-making process regarding the urban plan. Furthermore, the Act prescribed that an IUP proposal had to be discussed in the local community before it could be adopted. This meant that local communities could act as pressure groups in matters like housing, communal services, child and social welfare, education, culture, physical education, consumer protection, etc. (Simmie, 1989). By involving different stakeholders in the planning process, the planners' role shifted somewhat to finding a balance between different land-use needs and pressures and proposing alternatives (Pogačnik, 1987). The final proposal of both the urban plan and IUP had to be publicly displayed for at least 30 days and open for comments at least 45 days. Every remark had to be considered and an explanation provided in the event of its rejection (Sabor SRH, 1973).

\section{Environmental concerns}

The global expansion of environmental movement in the 1960s did not bypass Yugoslavia, where environmentalism started infiltrating both science and policy. The United Nation's efforts were recognised at the political level and a conference was held in Zagreb in 1972 on the occasion of Yugoslavia joining the Man and the Biosphere Programme. Its conclusion was the need to strengthen environmental protection in Yugoslavia (Branica, 1974; Lay, 1975). This was reflected in the new Act (Sabor SRH, 1973) which dedicated almost a fifth of its articles to protection and advancement of the human environment. Many environmental aspects, such as the protection of natural resources, and the use and maintenance of public spaces and private gardens, were supposed to be regulated by IUPs. Moreover, urban greenspace was considered important for protection from air and noise pollution, and natural ventilation (Sabor SRH, 1973).

The 1970s also brought a shift towards research in the UPIC, which focused on exploring the relationship between cities, planning and environmental protection. In collaboration with other research organisations, the UPIC came up with planning approaches for establishing ecological balance in space and local nature protection (Salaj, 1988). zajednica, OUR-a, SIZ-ova i stanovništva u odlučivanju o urbanističkom planu. Također je bilo propisano i da se prije usvajanja prijedlog PUP-a mora raspraviti na razini mjesnih zajednica. $\mathrm{Na}$ taj su način mjesne zajednice mogle djelovati kao lobističke grupe u pitanjima poput stanovanja, komunalnih usluga, dječje i socijalne skrbi, obrazovanja, kulture, fizičke kulture, zaštite potrošača i sl. (Simmie, 1989). Uključivanjem velikoga broja sudionika u planski proces uloga planera donekle se promijenila prema traženju i postizanju ravnoteže između različitih pritisaka i potreba u vezi s namjenom površina te predlaganju alternativnih rješenja (Pogačnik, 1987). Konačni prijedlog i urbanističkoga plana i PUP-a morao je proći 30 dana javnoga uvida i biti otvoren za komentiranje najmanje 45 dana. Svaka primjedba trebala se razmotriti i u slučaju odbijanja obrazložiti (Sabor SRH, 1973).

\section{Okolišni aspek†}

Globalno širenje pokreta za zaštitu okoliša iz 1960-ih nije zaobišlo ni tadašnju Jugoslaviju, gdje se environmentalizam počeo infiltrirati i u znanost i u politiku. Napori Ujedinjenih naroda prepoznati su razmjerno rano na političkoj razini te je u $\mathrm{Za}^{-}$ grebu 1972. održano savjetovanje povodom jugoslavenskoga pristupanja programu Čovjek i biosfera. Zaključeno je da je potrebno ojačati zaštitu okoliša u Jugoslaviji (Branica, 1974; Lay, 1975). Taj se zaključak odrazio već u novom zakonu iz 1973. koji je gotovo petinu svih članaka posvetio zaštiti i unaprjeđenju čovjekove okoline. Mnogi okolišni aspekti poput zaštite prirodnih resursa te korištenja i održavanja javnih površina i privatnih vrtova trebali su biti regulirani PUP-ovima. Štoviše, urbane zelene površine smatrane su važnima za zaštitu od onečišćenja zraka i zagađenja bukom te za prirodno prozračivanje gradova (Sabor SRH, 1973).

Sedamdesete su također donijele i značajniji pomak prema istraživanju u UIH-u, koji se u istraživačkom radu počeo fokusirati na odnos između gradova, planiranja i zaštite okoliša. U suradnji s drugim znanstvenim organizacijama UIH je osmislio planske pristupe za uspostavu ekološke ravnoteže u prostoru te lokalnu zaštitu prirode (Salaj, 1988).
Urban planning in socialist Croatia

Urbano planiranje u

Hrvatskoj tijekom socijalističkoga režima 
HRVATSKI

GEOGRAFSKI

GLASNIK

81/2, 5-41 (2019.)

\section{The period of non-expansive urban planning (1980-1991)}

The last decade of the socialist period can be considered as the beginning of the transition process, which accumulated in the late 1980s and culminated in the 1990s. Despite various economic and political reforms, the situation in Yugoslavia worsened throughout the 1970s. The deaths of key political figures in 1979 (Edvard Kardelj) and 1980 (Josip Broz Tito) were heralds of the demise of the socialist regime. The new leaders were more inclined toward nationalism than socialism (Benson, 2004) which led to the violent disintegration of Yugoslavia in 1991. In the meantime, the long-term planning perspective defined in the act of 1973 turned out to be limited. The "2000" plans resembled "largescale projects" difficult to achieve and indicated that a more flexible approach had to be used (UZGZ, 1985). Part of the changing perspective was also the process of slowing urban growth, with more urban renewal rather than spatial expansion.

\section{Legislation}

The planning acts of the 1970s proved inadequate, so new legislation was adopted in the early 1980s. In the new law, physical planning and construction were divided into separate acts. The Physical Planning and Spatial Organisation Act (Sabor SRH, 1980) was considerably shorter than the previous one, and it defined two types of city plans-GUP and implementation urban plan (IUP), with an option of passing other types of plans as well (Fig. 5). The act equated GUPs with urban plans drafted according to the act of 1973, which would remain valid if updated. Other types of plans could be urban projects, infrastructural plans, etc.

For the first time, certain aspects of planning were regulated by official rulebooks. The 1980 Act prescribed that the detailed regulations on the content and form of plans as well as spatial standards and norms would be issued by the republican body responsible for planning within a year of the Act's passing, but this was not done until 1985. Plans made between 1980 and 1985
Etapa neekspanzivnoga urbanog planiranja (1980. - 1991.)

Posljednje desetljeće socijalističkoga režima može se smatrati začetkom tranzicije koja se spremala u kasnim 80-ima i kulminirala u 90-ima. Unatoč različitim ekonomskim i političkim reformama stanje u Jugoslaviji se kroz 1970-e pogoršalo. Smrti ključnih figura socijalističke Jugoslavije 1979. (Kardelj) i 1980. (Tito) nagovijestile su slom socijalističkoga režima. Novi lideri bili su skloniji nacionalizmu nego socijalizmu (Benson, 2004), što je na kraju dovelo do nemirna raspada Jugoslavije 1991. U međuvremenu se dugoročna prostornoplanska perspektiva definirana u zakonu iz 1973. pokazala ograničenom. Tzv. planovi „2000.” više su nalikovali na goleme, teško ostvarive projekte, upućujući na potrebu ipak fleksibilnijega pristupa (UZGZ, 1985). Važan uzrok promjene perspektive bio je i proces usporavanja urbanoga rasta koji se u prostoru odrazio smanjenjem rasta većine gradova i povećanjem potreba obnove već postojećih dijelova grada.

\section{Zakonodavstvo}

Legislativa planiranja iz 1970 -ih pokazala se neodgovarajućom za usmjeravanje urbanoga razvoja pa je novi zakon usvojen već 1980. U novoj su legislativi prostorno planiranje i gradnja ponovno razdvojeni u odvojene zakone. Zakon o prostornom planiranju i uređivanju prostora (Sabor SRH, 1980) bio je znatno kraći od prethodnoga i definirao je dvije vrste gradskih planova - GUP i PUP, ali i ostavio mogućnost donošenja drugih vrsta planova (sl. 5). Očekivano, GUP je legalno izjednačen s urbanističkim planovima koji su se izrađivali prema zakonu iz 1973., a koji su ostali važeći ako su ažurirani sukladno novom zakonu. Druge vrste planova koji su se mogli donijeti bili su urbani projekti, planovi infrastrukturnih pojasa i sl.

Po prvi su put određeni vidovi planiranja regulirani posebnim propisima. Zakon iz 1980. odredio je da će detaljne propise o sadržaju i obliku planova, prostornim standardima i urbanističkim normativima donijeti republičko tijelo uprave nadležno za poslove prostornoga planiranja unutar godinu dana od stupanja spomenutoga zakona na snagu. Pravilnici su, međutim, doneseni tek 1985. uslijed čega su planovi do- 


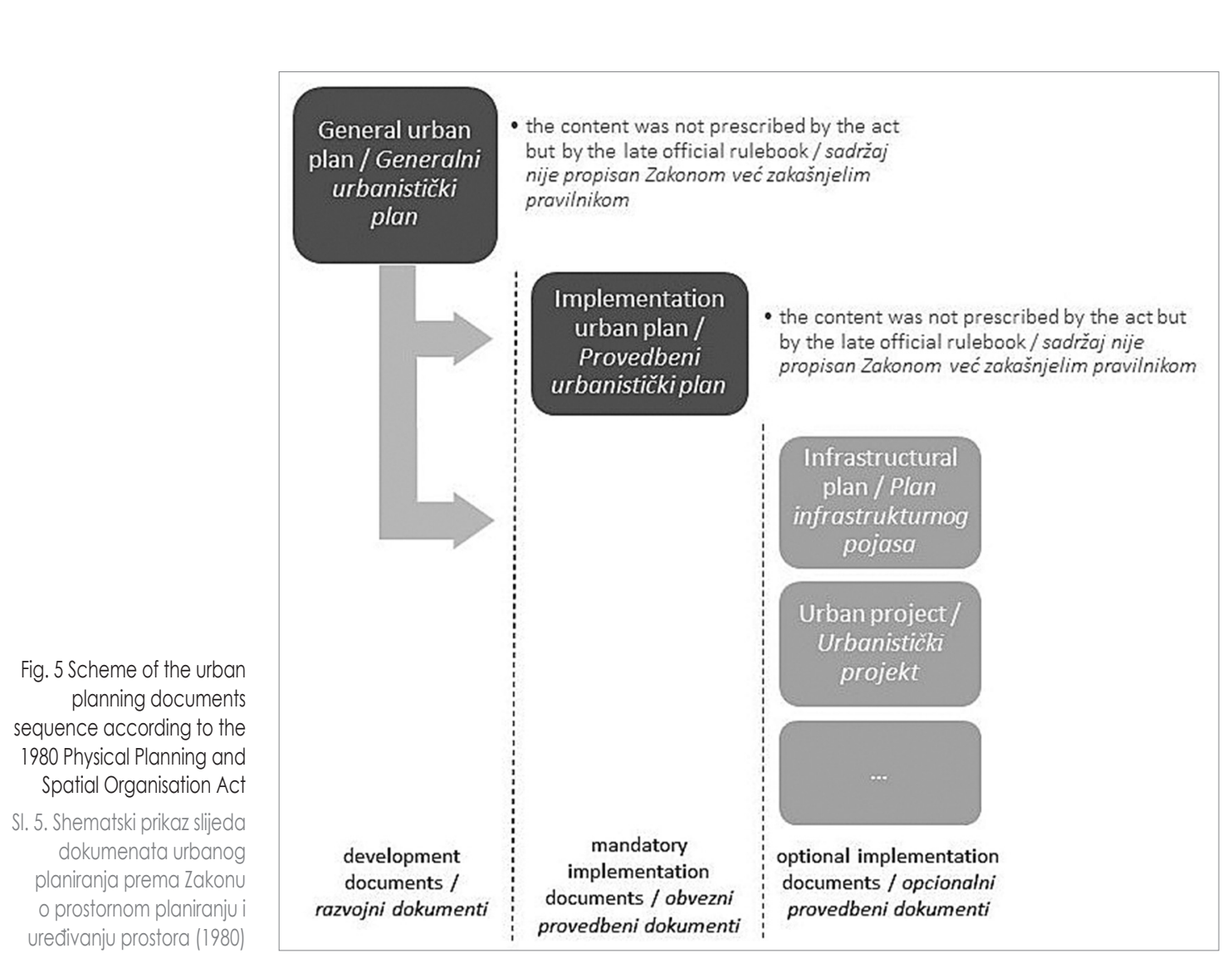

Urban planning in socialist Croatia

Urbano planiranje $u$

Hrvatskoj tijekom socijalističkoga režima were therefore incomplete and had to be modified once the rulebook was issued (Poropat et al., 2006).

\section{Relation to societal planning}

The 1980 Act set spatial planning as part of the singular system of societal planning, with the role of directing spatial distribution and ensuring compliance of all functions in space for the sake of achieving the goals and interests of socio-economic development of a given area. The next federal reform of the societal planning system, adopted in the act of 1985, strengthened the role of spatial planning, which resulted in the production of implementation plans oriented around investments (Dabović et al., 2017). This so-called "investment urbanism" thrived in the first post-socialist decade due to the lack of budget funds in many cities (Djordjević and Dabović, 2009). neseni u nereguliranom međurazdoblju bili nepotpuni i morali su biti modificirani kad su pravilnici stupili na snagu kako bi se s njima uskladili (Poropat i dr., 2006).

\section{Odnos prema društvenom planiranju}

Zakon iz 1980. definirao je prostorno planiranje dijelom jedinstvenoga sustava društvenoga planiranja s ulogom usmjeravanja prostornoga razmještaja svih funkcija u prostoru i osiguravanja usklađenosti među njima kako bi se ostvarili ciljevi i interesi društveno-gospodarskoga razvoja planiranoga prostora. Uskoro je uslijedila nova reforma sustava društvenoga planiranja, usvojena zakonom iz 1985., koja je ovaj put osnažila ulogu prostornoga planiranja, što je rezultiralo pojačanom izradom provedbenih planova usmjerenih na ulaganja (Dabović i dr., 2017). Takozvani „investicijski urbanizam” uveden u ovoj etapi posebice je bujao u najranijem postsocijalističkom razdoblju kad većini gradova proračun nije dostajao za razvojne projekte (Djordjević i Dabović, 2009). 


\section{Political-institutional responsibility}

The 1980 Act did not arrange the institutional framework for spatial and urban planning. There was, however, a provision that the republican body responsible for planning should bring additional, more detailed regulations on the planning process and documents. There was also still the provision that GUPs could not be adopted before obtaining the consent by the republic body responsible for spatial planning, which evaluated the compliance of the GUP with the relevant republican planning legislation.

\section{Urban planners and policy}

In contrast to the previous act, the one from 1980 did not specify the type of professional training that staff in plan-drafting organisations must have, only that they need to be registered for physical planning at the Ministry of Construction and Environmental Protection. However, the plans could also be drafted by administrative bodies founded for that purpose such as planning bureaus. Carrying out the most complex contemporary tasks, the UPIC began to organise its cadre thematically (housing, transport, tourism, recreation, etc.) in contrast to earlier disciplinary organisation. Furthermore, it shifted towards drafting plans that reassessed the earlier ambitious plans and attempted to settle spatial conflicts (Salaj, 1988).

Other previously-mentioned organisations, i.e. bureaus, unified within a group of spatial planning and design organisations (KOPROJEKT), as well as certain communal bureaus, continued to meaningfully contribute to the profession by drafting a large number of high-quality plans. A considerable number of experts continued supplementing knowledge from their disciplines (architecture, geography, construction, economics, sociology, etc.) at postgraduate programmes relating to urban, spatial and regional planning at the University of Zagreb's Faculties of Architecture and Science, as well as in other republics and abroad. Heads of physical plan drafting processes could, apart from architects, also be experts from other disciplines, depending on the internal organisation acts (e.g. geographers, economists, etc.), and this was practiced in bureaus in

\section{Političko-institucionalna nadležnost}

Zakon iz 1980. nije uredio institucionalni okvir prostornoga i urbanoga planiranja, no odredio je da republičko tijelo uprave nadležno za poslove prostornoga planiranja treba donijeti dodatne, iscrpnije propise o planskom procesu i dokumentima. Također je još uvijek stajala i odredba da se GUP-ovi nisu mogli usvojiti prije nego što je pribavljena suglasnost republičkoga tijela koje je ocjenjivalo usklađenost GUP-ova s republičkim prostornim planom.

\section{Urbani planeri i planerska praksa}

$\mathrm{Za}$ razliku od prethodnoga zakona, ovaj iz 1980 . nije specificirao kompetencije koje moraju posjedovati organizacije da bi mogle izrađivati planove, već samo da moraju biti registrirane za poslove prostornoga planiranja pri Ministarstvu graditeljstva i zaštite okoliša. Međutim, planove su također mogla izradivati i tijela uprave osnovana za obavljanje poslova prostornoga planiranja poput zavoda za prostorno planiranje. UIH koji je i dalje provodio najzahtjevnije planske zadatke počeo je tematski organizirati svoj rad i kadrove (stanovanje, promet, turizam, rekreacija itd.) u odnosu na prethodnu disciplinarnu organizaciju. Uz to je i počeo izrađivati planove koji su preispitivali ranije ambicioznije planove i nastojali rješavati prostorne konflikte (Salaj, 1988).

I ostale prije spomenute organizacije odnosno zavodi objedinjeni unutar grupacije prostornoplanerskih i projektnih organizacija (KOPROJEKT) kao i pojedini zavodi pri zajednicama općina ili u nekim većim općinama nastavili su značajno doprinositi ne samo brojem izrađenih planova nego i njihovom kvalitetom. Znatan broj stručnjaka nastavio je dopunjavati znanja iz matičnih struka (arhitektura, geografija, građevinarstvo, ekonomija, sociologija i dr.) na poslijediplomskim studijima koji su se ticali urbanizma, prostornoga ili regionalnoga planiranja na Arhitektonskom i Prirodoslovno-matematičkom fakultetu Sveučilišta u Zagrebu te u drugim republikama ili u inozemstvu. Voditelji izrade prostornih planova mogli su, osim arhitekata, biti i drugi stručnjaci, ovisno o unutarnjim aktima organizacije (ekonomisti, geografi i dr.) kao što se 
Zagreb, Zadar and Split. However, the same was not true for urban planning intended for drafting GUPs and IUPs.

\section{Plan execution}

Long-term GUPs were realised through midterm IUPs. After their adoption, cities had to monitor their implementation and modify the plans if they diverged from the spatial reality or social interests (Sabor SRH, 1980). In practice, consistent plan execution was the main difficulty of the planning system as plans were implemented by SMICs and OALs whose interests often diverged from those of plan-makers. Although cities formally controlled plan execution and issued permits for developers' projects, there were often departures from the official plan, and also unplanned land use, which were rarely sanctioned (Simmie, 1989).

\section{Public participation}

The role of local communities in the self-management system was strengthened. The Act (Sabor SRH, 1980, Art. 4) stated that 'working people and citizens in local communities and workers in [OALs] and [SMICs] from the territory of the local community decide on the spatial organisation of settlement for the sake of exercising their common interests for life and work in the local community'. Moreover, the Act gave responsible bodies the obligation to ensure the participation of all users of space in the procedure of designing the spatial organisation policy.

The tradition of public exhibition of plans was continued and the general public was invited to express their opinions of proposals either in writing or at the equivalent of public examinations (Simmie, 1989). As in the previous period, the communal assembly was obligated to consider submitted remarks and opinions of local communities, OALs and SMICs and provide an explanation in the case of their dismissal. In theory, the consent of concerned local communities remained a decisive factor of adoption of IUPs. to prakticiralo, primjerice, u zavodima u Zagrebu, Zadru i Splitu, ali to nije vrijedilo i za urbano planiranje odnosno za GUP-ove i PUP-ove.

\section{Provedba planova}

Dugoročni GUP-ovi ostvarivani su kroz srednjoročne PUP-ove. Nakon njihova usvajanja gradovi su trebali pratiti primjenu i modificirati planove ako bi prostorna stvarnost ili društveni interesi odstupali od njihovih postavaka (Sabor SRH, 1980). U praksi je dosljedna provedba planova bila glavna poteškoća u planskom sustavu s obzirom na to da su planove provodili OUR-i i SIZ-ovi čiji su se interesi često razlikovali od interesa koje su zastupali izrađivači planova. Unatoč tomu što su formalno općine nadzirale provedbu planova i izdavale dozvole za investicijske projekte, često su se dopuštala odstupanja od službenih planova i planirane namjene zemljišta te su ona rijetko kad sankcionirana (Simmie, 1989).

\section{Sudjelovanje javnosti}

Uloga mjesnih zajednica u sustavu samoupravljanja dodatno je osnažena. U članku 4. zakona iz 1980. stoji da „Radni ljudi i građani u mjesnim zajednicama i radnici u [OUR-ima] i [SIZ-ovima] s područja mjesne zajednice odlučuju o uređivanju naselja radi ostvarivanja svojih zajedničkih interesa za život i rad u mjesnoj zajednici." Štoviše, zakon je obvezivao nadležna tijela da osiguraju sudjelovanje svih sudionika u prostoru u postupku utvrđivanja politike uređenja prostora.

Nastavljena je i tradicija javnih uvida u prijedloge planova te se opća javnost pozivala na izražavanje mišljenja o prijedlozima bilo u pisanoj formi bilo usmeno tijekom javnih rasprava (Simmie, 1989). Kao i u prethodnom etapama, općinska skupština morala je razmotriti sve pristigle primjedbe i mišljenja mjesnih zajednica, OUR-a i SIZ-ova te dati obrazloženje za one primjedbe i prijedloge koji nisu usvojeni. U teoriji pristanak mjesne zajednice bio je odlučujući čimbenik pri usvajanju PUP-ova.
N. Tandarić

C. Watkins

C. D. Ives

Urban planning in socialist Croatia

Urbano planiranje $u$

Hrvatskoj tijekom socijalističkoga režima 


\section{Environmental concerns}

The 1980 Act defined that all space users were obligated to use space in a way that would ensure conditions for the preservation and advancement of the environment and the prevention of adverse effects that could endanger the values of the human environment. As Radeljak (2012) noted from the 1989 Spatial plan of SR Croatia, environmental protection was an issue for official consideration, but in reality, local and party interests were given an advantage. An example of a lack of both environmental considerations and respect for the local community's interests in practice can be found in the late-1980s case of large-scale residential construction in the then Dr. Mladen Stojanović local community (today called Jelenovac) in Zagreb (Štulhofer, 1991). Despite the local community's resistance to the project, which included the destruction of a woodland that was used for leisure and recreation and maintained the local ecological balance, the commune of Črnomerec was persistent in adopting and realising the IUP. In the end, the IUP was adopted despite the fact that the communal ombudsman for self-management had stated that the decision was invalid. The subsequent lawsuit, however, found in favour of the commune and the project was realised.

\section{Concluding remarks}

The socialist regime governed Croatia for almost half a century and the early goals of industrialisation, electrification, and urbanisation completely transformed the country in economic and social terms. The rich urban planning tradition of pre-war Croatia enabled the relatively rapid establishment of both urban and regional planning services and spatial planning policy in the 1950s. Over the second half of the $20^{\text {th }}$ century, it helped to contribute to the resolution of pressing issues and, as Franković (1985) remarked, urban planning was considered as a spatial aspect of planning the socialist society.

Socialist planning evolved in a close relationship with the development of socialist ideology (Bojić, 2018). From the very beginning, urban planning

\section{Okolišni aspekt}

Zakonom iz 1980. određeno je da su svi korisnici prostora dužni koristiti prostor na način kojim se osiguravaju uvjeti za očuvanje i unaprjeđenje okoline te sprječavaju štetne posljedice koje bi ugrozile te vrijednosti. No kako je Radeljak (2012) zaključila pri analizi Prostornoga plana SR Hrvatske, zaštita okoliša bila je samo deklarativna, a u praksi se često davala prednost lokalnim i pojedinačnim interesima. Dobar primjer zanemarivanja i okolišnoga aspekta i stavova i želja mjesne zajednice u praksi može se naći u slučaju projekta velike stambene izgradnje u mjesnoj zajednici Dr. Mladen Stojanović (danas mjesna zajednica Jelenovac) u Zagrebu s kraja 80-ih (Štulhofer, 1991). Projekt je uključivao uništenje lokalne šume kojom su se stanovnici koristili za odmor i rekreaciju i koja je održavala lokalnu ekološku ravnotežu. Unatoč otporu mjesne zajednice prema projektu Općina Črnomerec ustrajala je na usvajanju i realizaciji PUP-a kojim je projekt dopušten. Na kraju je PUP i usvojen usprkos tomu što je općinski pravobranitelj za samoupravljanje prosudio kako općinska odluka o donošenju PUP-a nije valjana. Konačno je i Vrhovni sud u slučaju tužbe mjesne zajednice protiv općine donio presudu u korist općine te je ostvarivanje projekta nastavljeno.

\section{Zaključak}

Socijalistički režim vladao je Hrvatskom gotovo pola stoljeća, a rani ciljevi industrijalizacije, elektrifikacije i urbanizacije u potpunosti su preobrazili državu u ekonomskom i društvenom smislu. Bogata tradicija urbanoga planiranja iz predratnoga razdoblja omogućila je razmjerno brzu uspostavu službe urbanoga i regionalnoga planiranja u 1950ima. Kroz drugu je polovicu 20. stoljeća urbano planiranje doprinijelo rješavanju mnogih važnih pitanja u Hrvatskoj i Jugoslaviji. Štoviše, kako je primijetio Franković (1985), urbano je planiranje smatrano prostornim aspektom izgradnje socijalističkoga društva.

Socijalističko planiranje razvijalo se u tijesnoj vezi sa socijalističkom ideologijom (Bojić, 2018). Od samih je početaka urbano planiranje viđeno kao 
was seen as vital for helping to create conditions for economic development. Until the mid-1960s, societal and five-year plans facilitated some of the most dynamic economic growth in the world (Dabović et al., 2017). Following the societal planning system reform in the 1960s, urban planning formally became a part of societal planning and its economic role was further emphasised. The 1970s brought change in the titles of legislation where spatial planning was given the central place and urban planning started being treated as a component thereof. In practice, urban planning remained the basic level of planning with a diverse variety of plans and its regulations had direct influence on people's lives and living conditions.

Frequent reforms, political and economic, characterised the socialist period and had a profound impact on urban planning. The peculiar course of events whereby urban planning acts (in Croatia) were regularly adopted just before essential systemic reforms that introduced relevant changes is interesting. The first federal planning regulation was adopted in 1949, just two years before the introduction of the self-management system. Then again, the urban planning act of 1961 preceded the constitutional reform of 1963 and the economic and societal planning system reforms of the mid1960s. The same happened with the 1973 planning act, which was implemented just a year before the new constitution. Since each reform initiated subsequent societal planning system reform, urban planning was practised in ever-changing conditions.

Political and economic decentralisation and subordinance to the societal planning system had both positive and negative sides for urban planning. While decentralisation enabled more adjustment of plans to local natural and socio-economic specificities, it also decreased control over the planning and implementation processes, which in turn allowed illegal developments. In practice, there was a considerable amount of unplanned building and construction, which in one way assisted economic and social development but in another hindered rational planning. Urban planners had very limited abilities to invoke higher-level authorities (e.g. republican or federal) to sanction the neglect of ključno u stvaranju uvjeta za gospodarski razvoj. Do sredine 1960-ih godina društveni i petogodišnji planovi uz podršku urbanih planova omogućili su jednu od najbrže rastućih stopa gospodarskoga rasta u svijetu u to doba (Dabović i dr., 2017). Nakon reforme društvenoga planiranja iz šezdesetih urbano je planiranje i formalno postalo dijelom sustava društvenoga planiranja te je njegova ekonomska uloga dodatno naglašena. U sedamdesetima je došlo do promjene u nazivu zakona kojom je prostorno planiranje preuzelo središnju poziciju, a dotadašnje centralno, urbano planiranje počelo se smatrati njegovom sastavnicom. U praksi je urbano planiranje ostalo osnovna razina planiranja s nizom različitih planova, a njihove su odredbe imale izravan učinak na živote ljudi kao i na lokalne životne uvjete.

Učestale političke i ekonomske reforme jedno su od osnovnih obilježja socijalističkoga razdoblja te su imale dubok utjecaj na urbano planiranje. Zanimljiv je repetitivni slijed događaja u kojima su zakoni o urbanom planiranju (u Hrvatskoj) redovito usvajani neposredno prije suštinskih sistemskih reforma koje su uvodile relevantne promjene. Prva federalna planska regulativa usvojena je 1949., samo dvije godine prije uvođenja sustava samoupravljanja. Godine 1961. ponovno je republički zakon o urbanom planiranju donesen dvije godine prije ustavne reforme i nekoliko godina prije reformi sustava ekonomskoga i društvenoga planiranja sredinom 60-ih. Isti se slijed potom ponovio kad je 1973. zakon usvojen samo godinu dana prije novoga ustava. Budući da je svaka ustavna i ekonomska reforma posljedično izazvala reformu sustava društvenoga planiranja, urbano je planiranje prakticirano u uvjetima stalnih mijena.

Politička i ekonomska decentralizacija i podloženost sustavu društvenoga planiranja imale su i pozitivnih i negativnih strana po urbano planiranje. Dok je decentralizacija omogućila veću prilagodbu planova lokalnim prirodnim i socioekonomskim posebnostima, također je i smanjila kontrolu nad procesima planiranja i implementacije, što se odrazilo u bujanju ilegalne gradnje. U praksi je neplanska gradnja bila prilično česta i dok je s jedne strane ona doprinosila gospodarskom i socijalnom razvoju, s druge je strane otežavala racionalno planiranje prostora. Urbani planeri imali su vrlo ograničene
N. Tandarić

C. Watkins

C. D. Ives

Urban planning in socialist Croatia

Urbano planiranje u

Hrvatskoj tijekom socijalističkoga režima 
plans. It is therefore not surprising that socialist planners often argued that many spatial problems could be solved by enhancing the role of technical planning instead of decentralising the planning system (Simmie, 1989). On the other hand, the subordination of urban to societal planning reduced the freedom of planners to implement practical over political solutions. In that sense, despite their relative freedom in the urban planning sector, they were still ultimately subordinate to politics (Seferagić, 2007).

Although some early plans paid considerable attention to the provision of public open space, environmental factors did not become an important part of urban planning until the 1970s. Only then were environmental concerns, along with nature-based solutions for pollution and risks, introduced into planning legislation as natural values worth preserving. Despite relatively advanced legal coverage, in practice, environmental protection remained subjugated to private interests and authorities often legitimised it by either giving permission to private investors' risky projects or turning a blind eye to informal development.

An important legacy of the socialist system was legal urban planning procedures and tools that are still used in modern Croatia. After its introduction in 1949, the general urban plan has remained the main document of urban planning to date, with the "semi-exception" of the 1970s when it was called an urban plan but was equated with the GUP adopted in both earlier and later decades. The detailed urban plan has also been an important legacy of socialist planning. Furthermore, even though they were made by the socialist government, the urban/spatial planning acts were oriented practically rather than ideologically, which is why the act of 1980 (with amendments) was used through 1994 (several years after Croatia's declaration of independence from Yugoslavia in 1991). Furthermore, socialist planners continued cultivating a century-long tradition of active engagement with western planning theories and methods, due to which Croatian planning did not lag behind Western Europe or the USA. Moreover, some advanced practices such as public display and participation and environmental concerns mogućnosti pozivanja nadležnih tijela na višim razinama (poput republičke) da sankcioniraju nepoštivanje planova. Stoga ne čudi da su socijalistički planeri često tvrdili kako bi mnogi prostorni problemi mogli biti riješeni kad bi se osnažio tehnički aspekt planiranja umjesto decentralizacije planskoga sustava (Simmie, 1989). S druge strane, podređenost urbanoga društvenom planiranju smanjila je slobodu planera u implementaciji praktičnih u korist političkih rješenja. U tom smislu, unatoč određenoj slobodi koja je postojala u sektoru urbanoga planiranja, planeri su svejedno bili ancilla politicae (Seferagić, 2007).

Iako su neki raniji planovi davali veliku pozornost stvaranju otvorenih javnih površina, okoliš nije postao važnim aspektom urbanoga planiranja sve do 1970-ih. Tada su pitanja okoliša uvedena u zakonsku regulativu kao prirodne vrijednosti vrijedne očuvanja te prirodna rješenja za zagađenje i prirodne rizike. Ipak, unatoč relativno veliku broju članaka kojima je okolišni aspekt bio pokriven u kasnijim zakonima, zaštita okoliša ostala je podređena privatnim interesima što su gradske vlasti često legitimirale ili davanjem dozvola za rizične projekte privatnih investitora ili okretanjem glave na ilegalnu gradnju.

Važna su ostavština socijalističkoga sustava pravne urbanoplanske procedure $\mathrm{i}$ alati koji se i dalje koriste u suvremenoj Hrvatskoj. Nakon uvođenja 1949. generalni urbanistički planovi ostali su osnovni dokument urbanoga planiranja sve do danas, uz „poluiznimku” iz 1970-ih kada su zvani urbanističkim planovima, ali su bili izjednačeni s GUP-ovima izrađenima prema prethodnim i kasnijim zakonima. Detaljni urbani planovi također su bitno nasljeđe socijalističkoga planiranja. Konačno, iako su ih izradile socijalističke vlasti, zakoni o urbanom/prostornom planiranju bili su usmjereni više praktično nego ideološki zbog čega je zakon iz 1980. (uz izmjene i dopune) korišten u Hrvatskoj i nakon proglašenja neovisnosti sve do 1994. Štoviše, socijalistički planeri nastavili su njegovati stoljetnu tradiciju aktivne interakcije sa zapadnjačkim teorijama i metodama planiranja zbog čega hrvatsko planiranje nije zaostajalo za onim u Zapadnoj Europi i SAD-u u tom razdoblju. Dapače, neke napredne prakse poput stavljanja planova na javni uvid, sudjelovanja javnosti te razmatranja okolišnih aspekata uvedene 
were introduced (at least legally) around the same time as in western planning. On the other hand, multidisciplinarity was delayed by several decades. Modern Croatian urban planning has continued to cultivate all practices inherited from the socialist period, and developed them further.

Given that many Croatian cities experienced the greatest growth in the post-war period, their contemporary form and structure reflect socialist plans considerably. We hope that providing the fundamental context in which these plans were made may serve planners to understand why modern cities look and function as they do and which barriers and opportunities they pose for today's urban planners. Moreover, we hope that the displayed evolution of planning practices may encourage planners to critically consider the current state of these practices and undertake steps towards further advancing them in their own work.

This work was carried out as part of the project Planning for cultural ecosystem services: A study of socialist and post-socialist Croatia funded by Arts and Humanities Research Council (Midlands3Cities). We would like to thank the support of the School of Geography, University of Nottingham. We also thank to two anonymous reviewers for their useful comments, suggestions and references. su (barem pravno) otprilike $\mathrm{u}$ isto vrijeme kao $\mathrm{i} u$ zapadnjačko planiranje. S druge je strane multidisciplinarnost u planiranje ušla s nekoliko desetljeća zaostatka. Suvremeno hrvatsko urbano planiranje nastavilo je njegovati prakse naslijeđene iz socijalističkoga razdoblja unaprjeđujući ih i dalje.

Budući da su mnogi hrvatski gradovi doživjeli snažan rast u razdoblju poslije Drugoga svjetskog rata, njihovi današnji oblik i struktura dobrim dijelom odražavaju socijalističke planove. Osvjetljavanje konteksta u kojem su ti planovi razvijani može poslužiti planerima da bolje razumiju pozadinu suvremene strukture, izgleda i funkcioniranja gradova te koje prepreke i mogućnosti to stavlja pred njihovo suvremeno urbano planiranje. Štoviše, valja se nadati da će prikazani razvoj planerskih praksi ohrabriti planere na kritičko sagledavanje njihova trenutnoga stanja te na poduzimanje koraka prema njihovu daljnjem unaprjeđivanju kroz vlastiti rad.

Ovaj je rad proveden u okviru projekta Planiranje kulturnib usluga ekosustava: Istraživanje u socijalističkoj i postsocijalistickoj Hrvatskoj koji je financiralo britansko Istraživačko vijeće za umjetnosti i humanističke znanosti - AHRC (Midlands3Cities). Željeli bismo zahvaliti Školi za geografiju Sveučilišta u Nottinghamu za podršku pri izradi rada. Zahvaljujemo također dvama anonimnim recenzentima na korisnim komentarima, prijedlozima i referencama.
Anonymous, 1980: Land-Use Policy in Yugoslavia, Habitat International 4 (46), 555-561.

Antolić, V., 1949: Regulacioni plan i direktivna regulaciona osnova Zagreba, Arbitektura 2, 5-30.

Arbutina, D., 2007: Glavna obilježja urbanističkog razvoja Zadra 1918.-1944., Narodni muzej Zadar, Zadar.

Benson, L., 2004: Yugoslavia: A Concise History, Palgrave Macmillan, London.

Blau, E., Rupnik, I., 2007: Project Zagreb: Transition as Condition, Strategy, Practice, Harvard University, Barcelona.

Bojić, N., 2018: Social and Physical Planning: Two Approaches to Territori- al Production in Socialist Yugoslavia between 1955 and 1963, Architectural Histories 6 (1), Art. 25, DOI: 10.5334/ ah.309.

Branica, M., 1974: Panel diskusija sudionika I. jugoslavenskog simpozija "Kemija i okoliš", Arbiv za higijenu rada i toksikologiju 25 (suppl.), 327-346.

Bukvić, N., 2012: Izvršno vijeće Sabora Narodne Rrepublike Hrvatske: Ustroj i djelovanje (1953-1963), Arbivski vjesnik 55, 9-46.

Burton, R. P., Dyckman, J. W., Fisher, J. C., 1966: Toward a system of social planning in Yugoslavia' in: Papers of XVIII. Congress of Regional Science Association, Vienna 1966, Regional Science Asso- ciation, Vienna, 75-86, DOI: 10.1111/ j.1435-5597.1967.tb01355.x.

Corkindale, J., 1997: Fifty Years of the Town and Country Planning Acts: Time to Privatise Land Development Rights?, Institute of Economic Affairs, London.

Dabović, T., Nedović-Budić, Z., Djordjević, D., 2017: Pursuit of integration in the former Yugoslavia's planning, Planning Perspectives 34 (2), 1-27, DOI: 10.1080/02665433.2017.1393628.

Dakić, S., Kritovac, F., Perković, Z., 1972: Društveni konflikti i prostorno planiranje, Sociologija i prostor 35-36, 54-62.

Djordjević, D., Dabović, T., 2009: System of spatial planning in Serbia: A critical overview, Dela 31, 143-157.
N. Tandarić

C. Watkins

C. D. Ives

Urban planning in socialist Croatia

Urbano planiranje $\mathbf{u}$

Hrvatskoj tijekom socijalističkoga režima

Acknowledgement Zahvala

Literature Literatura 
Došen, A., 2012: Planovi grada Gospića iz 18. stoljeća, Peristil 55 (1), 57-64.

Došen, A. 2016: Arhitektura i urbanizam grada Gospića između 1750. - 1830. in: Kraševac, I. (ed.): Klasicizam u $\mathrm{Hr}$ vatskoj, Institut za povijest umjetnosti, Zagreb, 243-263.

Dyckman, J.W., 1966: Social Planning, Social Planners, and Planned Societies, Journal of the American Planning Association 32 (2), 67-68, DOI: 10.1080/01944366608979360

Fisher, J. C., 1965: City Planning and Housing Administration in Yugoslavia, Urban Affairs Quarterly 1 (2), 59-71, DOI: $10.1177 / 107808746500100204$.

Franković, E., 1985: Urbanističko planiranje Zagreba od 1945. do 1985., $R a-$ dovi Instituta za povijest umjetnosti 9, 85-87.

French, R.A., Hamilton, F.E.I., 1979: The socialist city. Spatial structure and urban policy, John Wiley, Chichester.

Frković, M., 1966: The System of Social Planning in Yugoslavia, Federal Institute of Economic Planning, Beograd.

Glamuzina, N., Fuerst-Bjeliš, B., 2015: Historijska geografija Hrvatske, Sveučilište u Splitu, Split.

Grbić, Č., 1975: Samoupravljanje i država u razvoju socijalističkog samoupravnog sistema u Jugoslaviji, Politicka misao 12 (3), 86-114.

Hirt, S. A., 2005: Planning the post-communist city: Experiences from Sofia, International Planning Studies 10 (3-4), 219-240, DOI: 10.1080/13563470500378572.

Horvat, B., 1966: Planning in Yugoslavia, Jugoslavenski institut za ekonomska istraživanja, Beograd.

Katurić, I., 2016: Informal Housing in the framework of Housing and Welfare Systems in Post-Communist Croatia, Università degli Studi di Milano-Bicocca, Milano.

Kisić, D., Mlikota, A., 2017: Zadar - poslijeratna urbanističko-arbitektonska obnova: 1944.-1958., Državni arhiv Zadar, Zadar.

Krajnik, D., 2015: Bjelovarski ring u kontektu europske gradogradnje, Radovi Zavoda za znanstvenoistraživački i umjetnicki rad u Bjelovaru 9, 187-198.

Kranjčević, J., 2009: Obnova seoskih naselja 1945. godine - Divoselo, Vojnić, Vla- hović, Prostor, 17 (2), pp. 314-326.

Lay, V., 1975: Razvoj urbane sociologije u Hrvatskoj, Revija za sociologiju 5 (4), $12-25$

M., N., 1954: Regulatorna osnova Zagreba još uvijek nije prihvaćena, Čovjek i prostor 1 (1), 3-3.

Magaš, D., 2009: Prostorni razvoj Zadra 1945.-1991., in: Oršolić, T. (ed.): Zadar $i$ okolica od Drugoga svjetskog rato do Domovinskog rata: zbornik radova sa Znanstvenog skupa održanog 21. studenog 2007. u Zadru, HAZU, Zavod za povijesne znanosti u Zadru and Sveučilište u Zadru, Zagreb and Zadar, 274-347.

Magaš, D., 2013: Geografija Hrvatske, Sveučilište u Zadru, Odjel za geografiju and Meridijani, Zadar and Samobor.

Magaš, D., Lončarić, R., 2006: Litoralizacija i prostorno planske vizije hrvatskih priobalnih središta, in: Matas, $\mathrm{M}$ (ed.): Akademik Josip Roglić i njegovo djelo: međunarodni znanstveni skup, Makarska, 19.-22. travnja 2006.: zbornik radova, Hrvatsko geografsko društvo, Split, 245-268.

Magdalenić, I., 1971: Urbanizacija i socijalna diferencijacija s posebnim osvrtom na prostornu segregaciju unutar gradova, Sociologija sela 31-32, 62-71.

Maretić, M., 1959: Prostorno planiranje i program za projektiranje dječjih igrališta, Čovjek i prostor 83, 1-3

Marinović-Uzelac, A., 1989: Teorija namjene površina u urbanizmu, Tehnička knjiga, Zagreb.

Marinović-Uzelac, A., 1993: Urbanizam u novim uvjetima, Prostor 1 (1), 1-12.

Marinović-Uzelac, A., 2001: Prostorno planiranje, Dom i svijet, Zagreb.

Marx, K., Bakunin, M. A., Kropotkin, P., 2008: Writings on the Paris Commune, Red and Black Publishers, St. Petersburg.

Nedović-Budić, Z., Cavrić, B., 2006: Waves of planning: a framework for studying the evolution of planning systems and empirical insights from Serbia and Montenegro, Planning Perspectives 21 (4), 393-425, DOI: 10.1080/02665430600892146.

Padgett, J. F., 1973: Philosophy and social planning in Yugoslavia, Social Theory and Practice 2 (4), 439-458.
Peattie, L., 1981: Social Planning: The Attempt to Enter the Moral Order via the Technical Order, in: Thinking About Development, Plenum Press, New York, 53-69.

Perković, Z., 1979: Prognoze stanovništva u dosadašnjim planovima, demografska kretanja i planiranje budućeg razvoja Zagreba, Geografski glasnik 41-42 (1), 135-148.

Petrinović, Z., 1962: Urbanizam pred teškim i složenim zadacima, Čovjek i prostor $9,1-2$

Petrović, B., 1954: Prijedlog za organizaciju urbanističke službe, Čovjek i prostor $19,1-1$

Petrović, B., 1971: Odnos fenomena čovjekove sredine i prostornog planiranja, Život umjetnosti 15-16, 47-61.

Piha, B., 1973: Prostorno planiranje, Službeni list SFRJ, Beograd.

Pogačnik, A., 1987: Yugoslav Experience in the Decentralisation of Urban and Regional Planning Systems, Landscape and Urban Planning 14, 441-443, DOI: 10.1016/0169-2046(87)90055-7.

Poropat, A., Brščić, K., Velčić, E., 2006: The Hierarchy of Plans of Physical Planning in the Republic of Croatia and EU, in: Franković, B. (ed.): International Congress Energy and the Environment 2006, Hrvatski savez za sunčevu energiju, Rijeka, 139-152.

Premerl, T., 1986: Tragovi moderne u poslijeratnoj arhitekturi Hrvatske, Arbitektura 196-199, 14-21.

Premužić, M., 1949: Trideset godina Komunističke partije Jugoslavije, Arhitektura 2, III-VII.

Premužić, M., 1962: Petnaestogodišnjica Urbanističkog instituta NRH, Čovjek prostor $9,1-7$

Radeljak, P., 2012: Prostorno planiranje na području Šibensko-kninske županije od druge polovice 20. stoljeća, Sociologija $i$ prostor 50 (3), 345-377, DOI: 10.5673/ sip.50.3.4

Reiss, V., 2017: Viennese planning culture: Understanding change and continuity through the Hauptbanhoff, The University of British Columbia, Vancouver.

Rendulić, N., 1966: Kakve promjene predstoje u našem sistemu društvenog planiranja, Politička misao 3 (1-2), 45-56. 
Rogić, I., 2006: Odnos spram kuće za odmor u Hrvatskoj u strategiji urbanizacije 1945.-2005., Društvena istraživanja 15 (1-2), 3-26.

Rubić, I. 1953: Slavonski i Bosanski Brod: studija o ekonomsko-geografskoj strukturi grada i okoline, Gradski narodni odbor, Slavonski Brod.

Salaj, M. (ed.), 1988: Urbanistički institut SR Hrvatske: 1947.-1987., Urbanistički institut SR Hrvatske, Zagreb.

Schaffer, D. (ed.), 1988: Two Centuries of American Planning, The Johns Hopkins University Press, Baltimore.

Seferagić, D., 2007: Akteri društvenih promjena u urbanom prostoru Hrvatske, Sociologija i prostor 45 (3-4), 361-376.
Simmie, J. M., 1989: Self-management and town planning in Yugoslavia, The Town Planning Review 60 (3), 271-286.

Simmie, J. M., Hale, D. J., 1978: Urban Self-management in Yugoslavia, $R_{e}-$ gional Studies 12 (6), 701-712, DOI: $10.1080 / 09595237800185641$.

Slukan Altić, M., 2006: Počeci prostornog planiranja u gradu Koprivnici, Podravina $5(9), 19-31$.

Slukan Altić, M., 2012: Town planning of Zagreb $1862-1923$ as a part of European cultural circle, Ekonomska i ekohistorija 8 (1), 100-107.

Štulhofer, A., 1991: Ekološka mikro-kriza i urbani konflikt: studija slučaja dviju zagrebačkih mjesnih zajednica, Revija za sociologiju 22 (1), 177-190.

Ungar, P., 1949: Parkovi u Hrvatskoj, Arbitektura 2, 89-106.

Vresk, M., 1990: Grad u regionalnom i urbanom planiranju, Školska knjiga, Zagreb.

Wagenaar, C., 2011: Town Planning in the Netherlands since 1800: Responses to Enlightenment Ideas and Geopolitical Realities, 010 Publishers, Rotterdam.

Žuljić, S., 1975: Razvoj Zagreba i urbanizacija središnje Hrvatske, Hrvatski geografski glasnik 36-37, 43-57.

Sabor SRH, 1961: Zakon o urbanističkom i regionalnom prostornom planiranju, NN 21/61.

Sabor SRH, 1973: Zakon o prostornom uređenju i korištenju građevinskog zemljišta, NN 14/73.

Sabor SRH, 1980: Zakon o prostornom planiranju i uređivanju prostora, $N N$ 54/80.

Skupština SFRJ, 1958: Zakon o nacionalizaciji najamnih zgrada i građevinskog zemljišta, Službeni list FNRJ 52/58.

Skupština SFRJ, 1963: Ustav Socijalističke Federativne Republike Jugoslavije, Službeni list SFRJ 14/63.

Urbanistički zavod Grada Zagreba (UZGZ), 1985: Prostorni plan grada Zagreba: studija, Zagreb.

Vlada DFJ, 1945: Zakon o zaštiti narodnih dobara i njihovom upravljanju, Službeni list DFJ 36/45.

Vlada FNRJ, 1947: Osnovni zakon o eksproprijaciji, Službeni list FNRJ 28/47.

Vlada FNRJ, 1949: Osnovna uredba o generalnom urbanističkom planu, Službeni list FNRJ 78/49.

Neven Tandarić neven.tandaric@nottingham.ac.uk MSc, University of Nottingham, School of Geography, University Park, Nottingham, NG7 2RD, UK

\section{Charles Watkins $\quad$ charles.watkins@nottingham.ac.uk}

Professor, University of Nottingham, School of Geography, University Park,

Nottingham, NG7 2RD, UK

Christopher D. Ives _ chris.ives@nottingham.ac.uk

Assistant Professor, University of Nottingham, School of Geography, University Park,

Nottingham, NG7 2RD, UK
N. Tandarić

C. Watkins

C. D. Ives

Urban planning in socialist Croatia

Urbano planiranje u

Hrvatskoj tijekom socijalističkoga režima

Sources

Izvori

Authors

Autori 